Article

\title{
Mesenchymal Stem Cells in the Treatment of Human Spinal Cord Injury: The Effect on Individual Values of pNF-H, GFAP, S100 Proteins and Selected Growth Factors, Cytokines and Chemokines
}

\author{
Lucia Slovinska $^{1, *(\mathbb{D}}$, Denisa Harvanova ${ }^{1} \mathbb{D}$, Jana Janockova ${ }^{1} \mathbb{D}$, Jana Matejova ${ }^{1} \mathbb{D}$, Peter Cibur $^{2}$, \\ Marko Moravek ${ }^{1}$ (D) Timea Spakova ${ }^{1}$ and Jan Rosocha ${ }^{1}$
}

check for updates

Citation: Slovinska, L.; Harvanova, D.; Janockova, J.; Matejova, J.; Cibur, P.; Moravek, M.; Spakova, T.; Rosocha, J. Mesenchymal Stem Cells in the Treatment of Human Spinal Cord Injury: The Effect on Individual Values of pNF-H, GFAP, S100 Proteins and Selected Growth Factors, Cytokines and Chemokines. Curr Issues Mol. Biol. 2022, 44, 578-596. https://doi.org/10.3390/ cimb44020040

Academic Editor: Aij Lie Kwan

Received: 31 December 2021

Accepted: 21 January 2022

Published: 24 January 2022

Publisher's Note: MDPI stays neutral with regard to jurisdictional claims in published maps and institutional affiliations.

Copyright: (C) 2022 by the authors. Licensee MDPI, Basel, Switzerland. This article is an open access article distributed under the terms and conditions of the Creative Commons Attribution (CC BY) license (https:// creativecommons.org/licenses/by/ $4.0 /)$.
1 Associated Tissue Bank, Faculty of Medicine of P. J. Safarik University and L. Pasteur University Hospital, Tr. SNP 1, 04011 Kosice, Slovakia; denisa.harvanova@upjs.sk (D.H.); jana.janockova@upjs.sk (J.J.); jana.matejova@upjs.sk (J.M.); marko.moravek@student.upjs.sk (M.M.); timea.spakova@upjs.sk (T.S.); jan.rosocha@upjs.sk (J.R.)

2 Department of Trauma Surgery, Faculty of Medicine of P. J. Safarik University and L. Pasteur University Hospital, Rastislavova 43, 04190 Kosice, Slovakia; peter.cibur@upjs.sk

* Correspondence: lucia.slovinska@upjs.sk

\begin{abstract}
At present, there is no effective way to treat the consequences of spinal cord injury (SCI). SCI leads to the death of neural and glial cells and widespread neuroinflammation with persisting for several weeks after the injury. Mesenchymal stem cells (MSCs) therapy is one of the most promising approaches in the treatment of this injury. The aim of this study was to characterize the expression profile of multiple cytokines, chemokines, growth factors, and so-called neuromarkers in the serum of an SCI patient treated with autologous bone marrow-derived MSCs (BM-MSCs). SCI resulted in a significant increase in the levels of neuromarkers and proteins involved in the inflammatory process. BM-MSCs administration resulted in significant changes in the levels of neuromarkers (S100, GFAP, and pNF-H) as well as changes in the expression of proteins and growth factors involved in the inflammatory response following SCI in the serum of a patient with traumatic SCI. Our preliminary results encouraged that BM-MSCs with their neuroprotective and immunomodulatory effects could affect the repair process after injury.
\end{abstract}

Keywords: spinal cord injury; mesenchymal stem cells; cell therapy; cytokines; neuromarkers

\section{Introduction}

Spinal cord injury (SCI) is a devastating process leading to permanent neurological deficits for which there is currently no effective treatment. Injury, which comprises primary and secondary phases, provokes a cascade of events, that includes disruption of axons and blood vessels, primarily the damage to the blood-spinal cord barrier, extensive necrotic cell death, axon degeneration, demyelination, and the beginning of an immune response [1]. These destructive processes result in an incurable failure of the sensory, motor, and autonomic functions under the site of injury due to the limited regenerative capacity of the central nervous system (CNS). Usually, SCI starts with an accidental primary mechanical injury. Most SCI cases in humans of primary injury are impact/vertebral dislocations with persistent compression of the spinal cord. The majority of patients are left paralyzed with limited daily activities, which have serious psychosocial effects that are exhausting for patients and their immediate surroundings [2]. The secondary injury is the most crucial phase in the pathophysiological process of SCI concerns, where complex biochemical changes occur. Secondary changes include disturbance of local ionic concentrations, inflammation, vascular dysfunction through the spinal cord, edema, ischemia, cell apoptosis, excitotoxicity, and demyelination process, accumulation of inhibitory molecules, insufficient trophic 
factor support, and glial scar formation with a dual role in the pathological process of SCI, both protective and inhibitory [3]. All these processes together impair the regeneration process and lead to further death of neural and glial cells, widespread neuroinflammation, and persists for several weeks after injury [4,5].

Cell transplantation therapies are one of the promising strategies for the treatment of SCI. Different types of cells are the focus of attention and research for example neural stem cells [6-8], Schwann cells [9,10], olfactory ensheathing cells [11], glial precursor cells $[12,13]$, based on their potential to eliminate the consequences of SCI, to replace lost neural tissue at SCI sites, such as support and promote axonal growth, improve myelination and bridge the wound site [14]. The most studied cell types used in SCI research are mesenchymal stem cells (MSCs). The International Society for Cellular Therapy (ISCT) defines these cells as being able to adhere to plastic culture dishes, with specific surface antigen expression (positive for CD73, CD90, CD105, negative for CD45, CD34, CD14 or CD11b, CD79 alpha or CD19, and HLA-DR) and with capacity for trilineage mesenchymal differentiation in vitro [15]. MSCs are easy to obtain and proliferate, with minimal ethical or immunological issues. MSCs can be isolated from human bone marrow (BM) from the superior iliac crest of the pelvis [16]. Other resources from which MSCs can be isolated are adipose tissue [17], umbilical cord Wharton's Jelly [18,19], human placenta tissue [20], amniotic, chorionic membranes, umbilical cord, and placental decidua [21,22].

Inflammation is a key goal of experimental and clinical treatment. MSCs play an important role in this process because it was found that MSCs can suppress inflammation [23,24], down-regulate the microglia activity [25], minimize secondary injury, and protect the neural elements that survived the initial mechanical insult. Additionally, MSCs have been shown to differentiate into neural stem cells, neuron-like cells and stimulate neural stem cell proliferation to rebuild the damaged nerve tissue [26,27]. It has been reported that MSCs therapy after SCI leads to reduction of astrocytes proliferation and inhibition of glial scar formation [28].

MSCs perform their regeneration activity not only through the cell replacement of injured cells but also via strong paracrine impact. MSCs have been found to secrete a broad range of trophic factors, bioactive molecules with neuroprotective and neuroregulatory effects $[29,30]$ to suppress immune response [31-33] and induce angiogenesis [34]. MSCs mediate direct neuroprotection by reducing neuronal sensitivity to glutamate receptor ligands and altering gene expression [28] Moreover, MSCs also express several interleukins, cytokines, and growth factors, such as interleukins IL-6 and IL-8, tissue inhibitor of metalloproteinase 2 (TIMP-2), monocyte chemoattractant protein-1 (MCP-1) and vascular endothelial growth factor (VEGF) detected by antibody array [35].

Predicting the long-term outcome after SCI and evaluating the effectiveness of cell therapy is an important component of the treatment strategy. Biomarkers that can easily be repeatedly measured within the blood or cerebrospinal fluid (CSF) of the patients to determine progressive neurological condition would be highly beneficial, as it would allow rapid determination as to whether the patient was improving, worsening, or showed sustained neurological stability in response to their current treatment, thus providing a biological surrogate outcome measure. The rupture of the blood-brain barrier (BBB) and either damage to the neurons and glia of the spinal cord tracts results in the release of biomarkers, largely cellular components, which are specific in the indication of nervous tissue damage and include neurofilaments (NF), S100 calcium-binding protein $\beta$ (S100 $\beta$ ) and glial fibrillary acidic protein (GFAP). GFAP, the main intermediary filament of astrocytes, is found only in the CNS and is upregulated in reactive gliosis following CNS injury [36]. GFAP is more astrocyte specific than S100 and the level of GFAP in the bloodstream increases as a result of rapid astrocyte destruction [37].

The members of the S100 protein family are multifunctional proteins involved in the regulation of a wide range of cellular processes. One of the members of this large family is the S100B calcium-binding protein physiologically mainly produced by astrocytes in the CNS [38] and its increased expression, as well as that of GFAP in blood and CSF 
represents a hallmark of astrocytic reaction to neural injury (reactive astrogliosis). Elevated levels of protein S100B originating from necrotic tissues might enhance or even amplify neurodegeneration by S100B-induced apoptosis. Measuring the level of S100B protein in serum and CSF had a potential value in the diagnosis of SCI in animal models $[39,40]$. These studies demonstrated that levels of S100B in serum and CSF significantly increased after experimental SCI in a time-dependent manner and therefore may be evaluated as a specific biomarker for acute SCI.

There are three major subunits of neurofilaments based on molecular weight, namely heavy (NF-H), medium (NF-M), and light (NF-L). A major structural component of large motor axons is the phosphorylated neurofilament subunit NF-H (pNF-H). It can be detected in significant amounts in CSF or serum as a result of neuronal loss after injury [41]. It is released from damaged and diseased neurons in significant amounts and may serve as a biomarker of neuronal damage in patients with amyotrophic lateral sclerosis [42], aneurysmal subarachnoid hemorrhage [43], and spinal cord injury [44]. Because neurofilaments are found only in neurons, the detection of released neurofilament subunits clearly reflects the level of damaged or destroyed neurons. The concentration of pNF-H should be useful for predicting the prognosis of each patient.

In our study, autologous bone marrow-derived MSCs (BM-MSCs) were isolated and expanded in vitro. After transplantation of BM-MSCs to a patient with SCI, the blood and CSF were analyzed for the presence of the pNF-H, S100 protein, and GFAP protein. Moreover, the dynamic changes to the chemokine/cytokine/growth factors' profile in serum during the period of BM-MSCs treatment of a patient after SCI were examined (Figure 1).

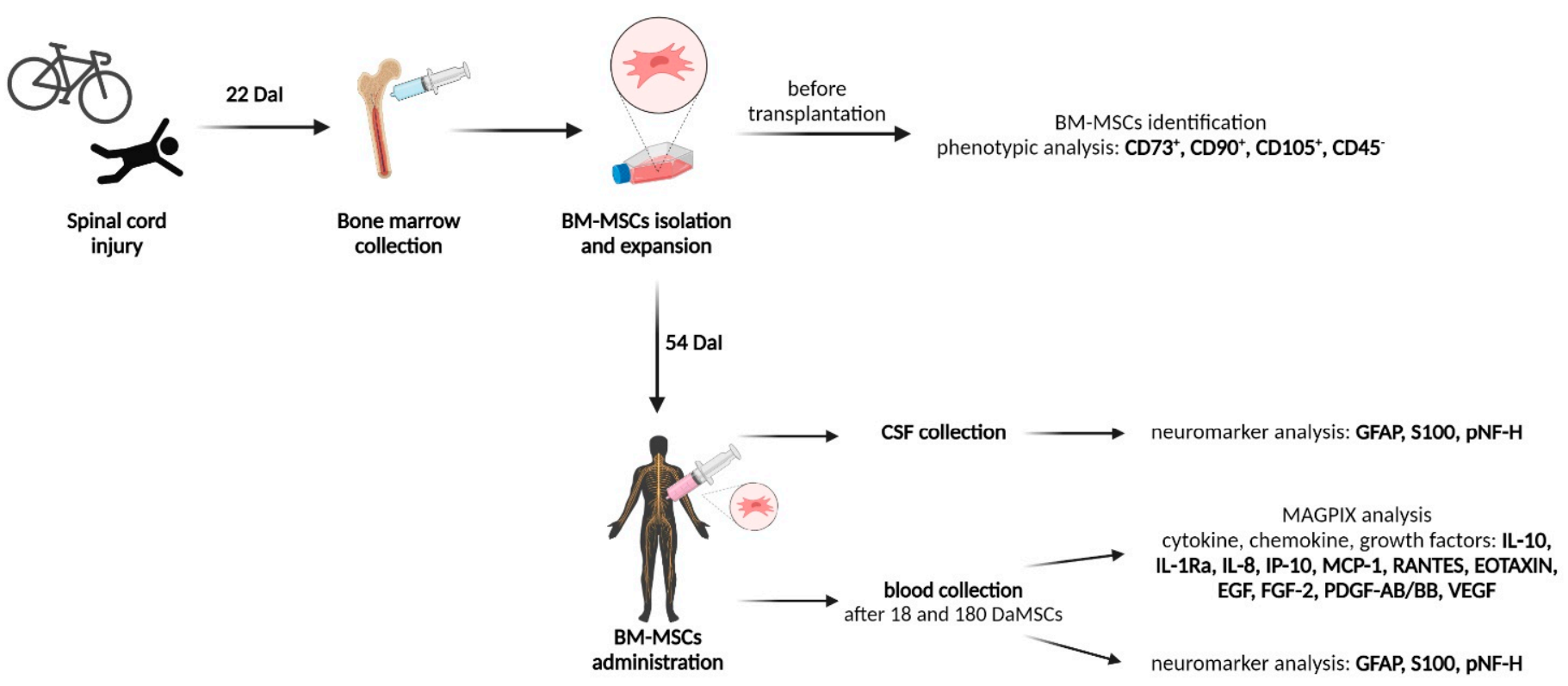

Figure 1. Schematic overview of the course of autologous bone marrow-derived mesenchymal stem cells (BM-MSCs) therapy in a patient with an injured spinal cord. DaI-Days after Injury, DaMSCs-Days after BM-MSCs transplantation. (Created with BioRender.com). 


\section{Results and Discussion}

In our study, we have performed a descriptive analysis of the serum proteins' level in the response to autologous BM-MSCs therapy of traumatic SCI. Cell transplantation treatment offers great potential to enhance the regeneration process after the injury. The blood and CSF of the BM-MSCs-treated patient were analyzed for the presence of the pNF-H, S100 protein, and GFAP protein. The chemokine/cytokine/growth factors' profile was also observed in the serum during the follow-up period after the BM-MSCs treatment.

\subsection{Patient}

The patient was a 35-year-old male who had a bicycle accident. He has a complete transverse lesion at the level of thoracic 6 (T6), completely lost the sensation and movements below T6 with no voluntary anal contraction and sensation to deep anal pressure. During 1-year follow-up, we did not find any clinically adverse reaction related to the BM-MSCs transplantation.

\subsection{BM-MSCs Cultivation and Administration}

The majority of cell therapy trials use autologous cells, specifically stem cells, but MSCs are dominant in registered clinical trials. The limiting and decisive factors in the use of MSCs in cell therapy of human SCI in clinical practice are mainly the type of MSCs-the origin from which the cells are isolated, doses, cell delivery method, and precise timing of cell administration after injury $[45,46]$.

Twenty-two days after the injury, the patient's BM was collected in an amount of $25 \mathrm{~mL}$. Subsequently, according to standard procedures, BM-MSCs were isolated and placed in 15 culture flasks with an area of $75 \mathrm{~cm}^{2}$. BM-MSCs were expanded under standard in vitro conditions. The cultivation itself lasted 32 days and finally, 54 days after the injury (DaI), the cells were ready for application in an amount of $4.08 \times 10^{6} / \mathrm{mL}$ with $92.8 \%$ viability. In cell therapy trials the intrathecal cell delivery of MSCs predominates [45]. It was demonstrated that the injection of stem cells directly into the spinal cord is safe with minimal side effects. Moreover, intrathecal MSCs injection predominated over intravenous or intramedullary injection of stem cells in the clinical trials examining the use of stem cells in the treatment of SCI; whereas the time frame was 8 weeks after injury with the transplanted cell numbers ranging from $1 \times 10^{5}$ to $40 \times 10^{7}$ [47]. Although it was recognized, that any intervention in the treatment of SCI is effective at an early time point, within the first month after injury [14]. In our case, the autologous BM-MSCs were administered 54 DaI. As each organism is unique, also the cells derived from it behave with slight deviations from the standard. The slight prolongation of time from injury to cell application was due to the need to initiate the proliferation of autologous BM-MSCs and to achieve the required confluent cell layer during in vitro cultivation. Cell cultivation and the cultivation result itself can be influenced by several factors. Among other factors, the aging of MSCs can be a critical factor that affects the results of cell therapy. Transplantation of MSCs from young donors seems to provide better functional recovery through anti-inflammatory effects, vascular maturation, and neurogenesis potentially due to the dominance of trophic factor secretion [48]. Fortunately, the neurogenic differentiation capacity of MSCs is not correlated with donor age [49].

\subsection{Phenotypic Analysis of BM-MSCs}

Before application, MSC-specific markers were evaluated according to ISCT minimal definition criteria [15]. Cells did not express hematopoietic lineage marker CD45 (1.34\%) and were positive for CD73 (99.0\%), CD90 (97.2\%), and CD105 (95.9\%) thereby demonstrating a characteristic immunophenotype of human BM-MSCs (Figure 2). 

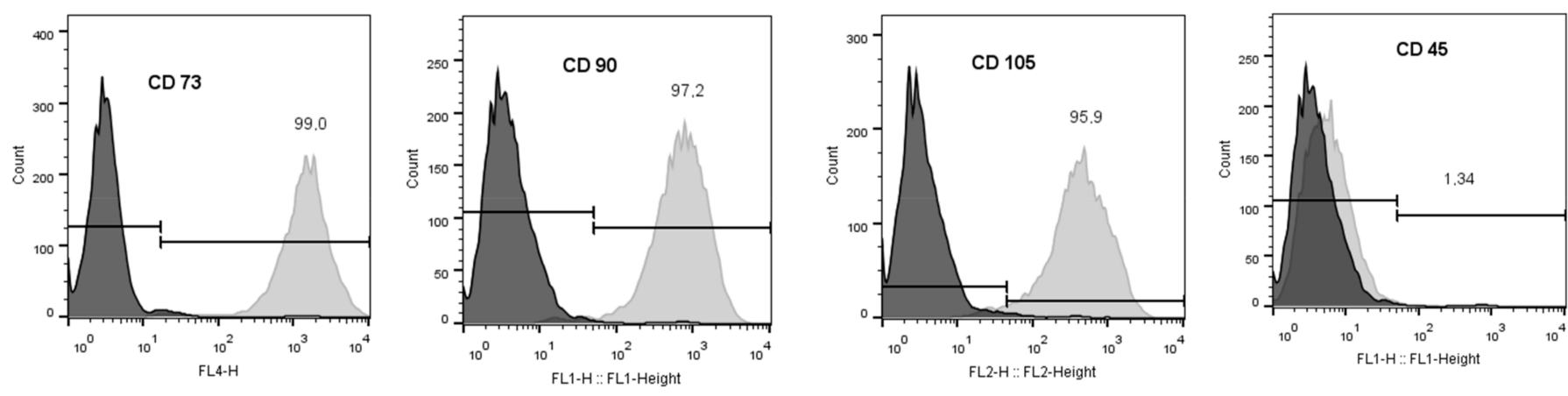

Figure 2. Surface markers expression in BM-MSCs. BM-MSCs were confirmed by flow cytometry analysis as positive for CD73 (99.00\%), CD90 (97.2\%), CD105 (95.9\%), and negative for CD45 (1.34\%).

\subsection{The Levels of S100, GFAP and pNF-H Protein in the Serum and the CSF of a SCI Patient Treated with Autologous BM-MSCs}

In contrast to a large number of reports on biomarkers in structural brain damage, only a few studies have investigated the role of biomarkers in patients with SCI. Quantitative evaluation of serum biomarkers could help to evaluate the course of damage and especially the success of tissue regeneration after the treatment.

In the first two weeks after the spinal cord injury (14 DaI), high levels of S100, GFAP, and pNF-H proteins were detected in the serum. The serum levels of all three proteins were significantly $(p<0.001)$ higher than in the controls of healthy individuals $(\mathrm{S} 100=45.22 \pm 1.81 \mathrm{pg} / \mathrm{mL}$ vs. $0.81 \pm 0.01 \mathrm{pg} / \mathrm{mL}, \mathrm{GFAP}=1.20 \pm 0.04 \mathrm{ng} / \mathrm{mL}$ vs. $0.39 \pm 0.03 \mathrm{ng} / \mathrm{mL}, \mathrm{pNF}-\mathrm{H}=11.66 \pm 0.47 \mathrm{ng} / \mathrm{mL}$ vs. $4,70 \pm 0.14 \mathrm{ng} / \mathrm{mL}$ ), with a tendency to fluctuate slightly over the next forty days (Figure 3). High levels of individual markers tended to persist for more than a month. Even six days before the application of the BM-MSCs, the protein levels maintained at significantly high values in comparison with controls of healthy individuals ( $\mathrm{S} 100=46.53 \pm 1.09 \mathrm{pg} / \mathrm{mL}$ at $48 \mathrm{DaI}$ vs. $0.81 \pm 0.01 \mathrm{pg} / \mathrm{mL}$ in controls, GFAP $=0.82 \pm 0.1 \mathrm{ng} / \mathrm{mL}$ at $48 \mathrm{DaI}$ vs. $0.39 \pm 0.03 \mathrm{ng} / \mathrm{mL}$ in controls, $\mathrm{pNF}-$ $\mathrm{H}=8.51 \pm 0.59 \mathrm{ng} / \mathrm{mL}$ at $48 \mathrm{DaI}$ vs. $4.71 \pm 0.14 \mathrm{ng} / \mathrm{mL}$ in controls). Generally, the detected high levels of S100, GFAP, and pNF-H proteins are directly related to the devastating consequences of the damage of the cells and spinal cord. High levels of pNF-H reflect progressive axonal loss due to secondary damage [50], whereas high levels of S100 and GFAP protein reveal glial cell degradation and rising blood levels of S100 protein mimic the severity of mechanical spinal cord injury [39,51]. Moreover, other studies determined that the pNF-H level in plasma was elevated in response to SCI and positively correlates with the severity of the SCI $[52,53]$. Elevated levels of GFAP were also reported in the serum of multiple sclerosis patients [54]. In our case, the autologous BM-MSCs were transplanted at day $54 \mathrm{DaI}$. A significant decrease in the serum level of mainly glial proteins, namely S100 $(p<0.001)$ and GFAP $(p<0.01)$ was detected after the transplantation at 18 DaMSC. The serum level of S100 protein decreased almost 3-fold $(46.53 \pm 1.09 \mathrm{pg} / \mathrm{mL}$ at $48 \mathrm{DaI}$ vs. $15.18 \pm 1.30 \mathrm{pg} / \mathrm{mL}$ at $18 \mathrm{DaMSC}, p<0.001)$ and the level of GFAP protein decreased two and a half times $(0.81 \pm 0.01 \mathrm{ng} / \mathrm{mL}$ at $48 \mathrm{DaI}$ vs. $0.31 \pm 0.09 \mathrm{ng} / \mathrm{mL}$ at $18 \mathrm{DaMSC}$, $p<0.01$ ) in comparison with theirs levels before BM-MSCs application at $48 \mathrm{DaI}$. In the following 6 months after BM-MSCs transplantation, there was a further decrease in glial protein levels with a tendency to approach the values of healthy individuals. Regarding the $\mathrm{pNF}-\mathrm{H}$ protein, there were no significant changes in its level after BM-MSCs application during the follow-up period. After the cell transplantation, there was a decrease in pNF-H protein level during the follow-up period, but not to the extent that we found in glial proteins. The prolonged increase in plasma pNF-H in patients with central nervous system disorders may be caused due to continuous axonal degeneration, such as Wallerian degeneration or secondary damage of axons [53]. The release of GFAP protein into CSF and the bloodstream with its increasing level in these fluids is a result of the mechanical disruption of the BBB integrity and of the disruption of the structural integrity of astrocytes 
at the same time. Furthermore, the major components of the axonal cytoskeleton-the neurofilaments - are released into CSF because of the axonal damage during neurodegeneration. Their levels in the CSF can be modified by the action of treatments commonly used in multiple sclerosis [55]. Therefore, the levels of S100 and GFAP protein in CSF of our patient was about 30-fold higher in comparison to the serum levels before BM-MSCs transplantation: $1559 \pm 56.57 \mathrm{pg} / \mathrm{mL}$ in CSF vs. $46.53 \pm 1.09 \mathrm{pg} / \mathrm{mL}$ in serum at $48 \mathrm{DaI}$ for S100, $28.34 \pm 1.63 \mathrm{ng} / \mathrm{mL}$ in CSF vs. $0.81 \pm 0.01 \mathrm{ng} / \mathrm{mL}$ in serum at $48 \mathrm{DaI}$ for GFAP (Figure 4). Detected glial protein levels in CSF were significantly higher than the pNF-H protein level. Because pNF-H is found only in axons, its detection in CSF, blood, or other body fluids indicates the release of this protein from axons. Cerebrospinal fluid levels of GFAP and pNF-H are elevated also in patients with spinal cord tethering [56], where levels of GFAP and pNF-H in CSF might reflect the ongoing scar formation and neuronal injury potentially responsible for progressive neurological deterioration. The concentration of pNF-H protein determined in the patient's CSF was $11.44 \pm 1.22 \mathrm{ng} / \mathrm{mL}$ and reflected the severity of spinal cord injury. The measured level of pNF-H protein in CSF was almost 10-fold higher when compared with the values obtained in a previous study [57]. In this study, the normal level of pNF-H in human CSF was set less than or equal to $0.94 \mathrm{ng} / \mathrm{mL}$ [57]. Our results are consistent with the finding, that the pNF-H levels in CSF from the patients with SCI were 5-10 times higher than the normal [44]. We evaluated dramatic changes in the levels of proteins, mainly of glial cells, when a significant decrease in S100 and GFAP protein levels in the serum were determined after the administration of autologous BM-MSCs at 18 DaMSC and 180 DaMSC, respectively. Therapeutic responses in the acute stage of SCI are not only due to intervention but also because of autorecovery $(6-13 \%)$ [58]. However, in our case, in both glial proteins, there was a decrease of more than 50\% in the serum levels after BM-MSCs treatment. At 6 months (180 DaMSC) after MSCs transplantation, both glial proteins maintained this trend, with approaching values that of healthy individuals. In addition to cell death, reactive astrogliosis occurs during secondary spinal cord injury, which is characterized by enhanced GFAP expression [59]. This apparent decline of both glial proteins in our study can be attributed to the response to the BM-MSCs-based therapeutic intervention. Application of BM-MSCs to the injured spinal cord could protect astrocytes from apoptosis and reduce GFAP overexpression. Human MSCs exert neuroprotection against stroke in vitro at least in part via an anti-apoptotic mechanism [60]. A similar finding was demonstrated by a previous study [61]. The authors suggested that paracrine factors secreted by MSCs promote astrocyte survival and are associated with GFAP downregulation after ischemic stroke in vitro via inhibition of two important mediators of the cellular response to external stimuli-p38 MAPK and JNK [61].

\subsection{BM-MSCs Influenced Cytokine/Chemokine Levels in Injured Spinal Cord}

One of the key factors in secondary injury after SCI is inflammation. Therefore, subsequent successful treatment must focus on the suppression of this process and initiate repair events. The precise mechanism by which transplantation of BM-MSCs promotes functional recovery after SCI is still unclear. One of the options is that bioactive molecules secreted from the MSCs ameliorate functional deficits resulted from the damage [46]. Cytokines and growth factors with neuroprotective and regeneration-promoting effects belong to these molecules. To investigate the function of BM-MSCs in this process, we quantified the multiple inflammatory cytokines, chemokines, and growth factors in the patient's serum using the multiplex techniques Magpix, where we can analyze one marker in the context of others in a wide dynamic range. 

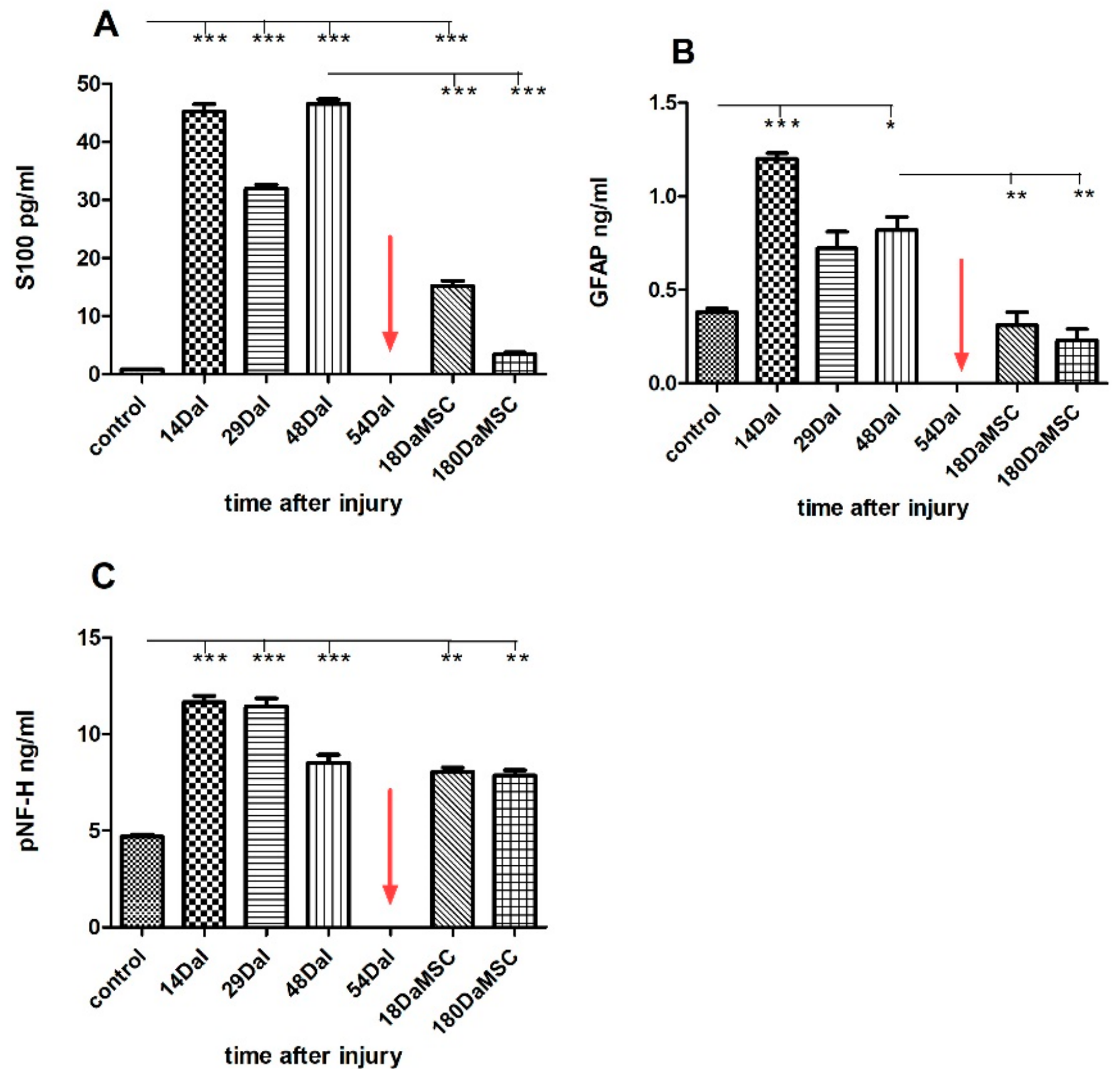

Figure 3. The level of S100 (A), GFAP (B), and pNF-H (C) protein in the serum of an SCI patient treated with autologous BM-MSCs before and after the treatment. SCI caused a significant increase in S100, GFAP, and pNF-H protein levels in the patient's serum in comparison with healthy controls (A-C). Administration of autologous BM-MSCs to the patient at day 54 post-injury resulted in a significant decrease in the levels of S100 and GFAP proteins in 18 days and 180 days follow-up period $(\mathbf{A}, \mathbf{B})$. The red arrow indicates the administration time of autologous BM-MSCs. Data are shown as the mean $\pm \mathrm{SD},{ }^{*} p<0.05,{ }^{* *} p<0.01,{ }^{* * *} p<0.001$. DaI-Days after Injury, DaMSC-Days after BM-MSCs transplantation. 


\section{CSF at 54Dal}

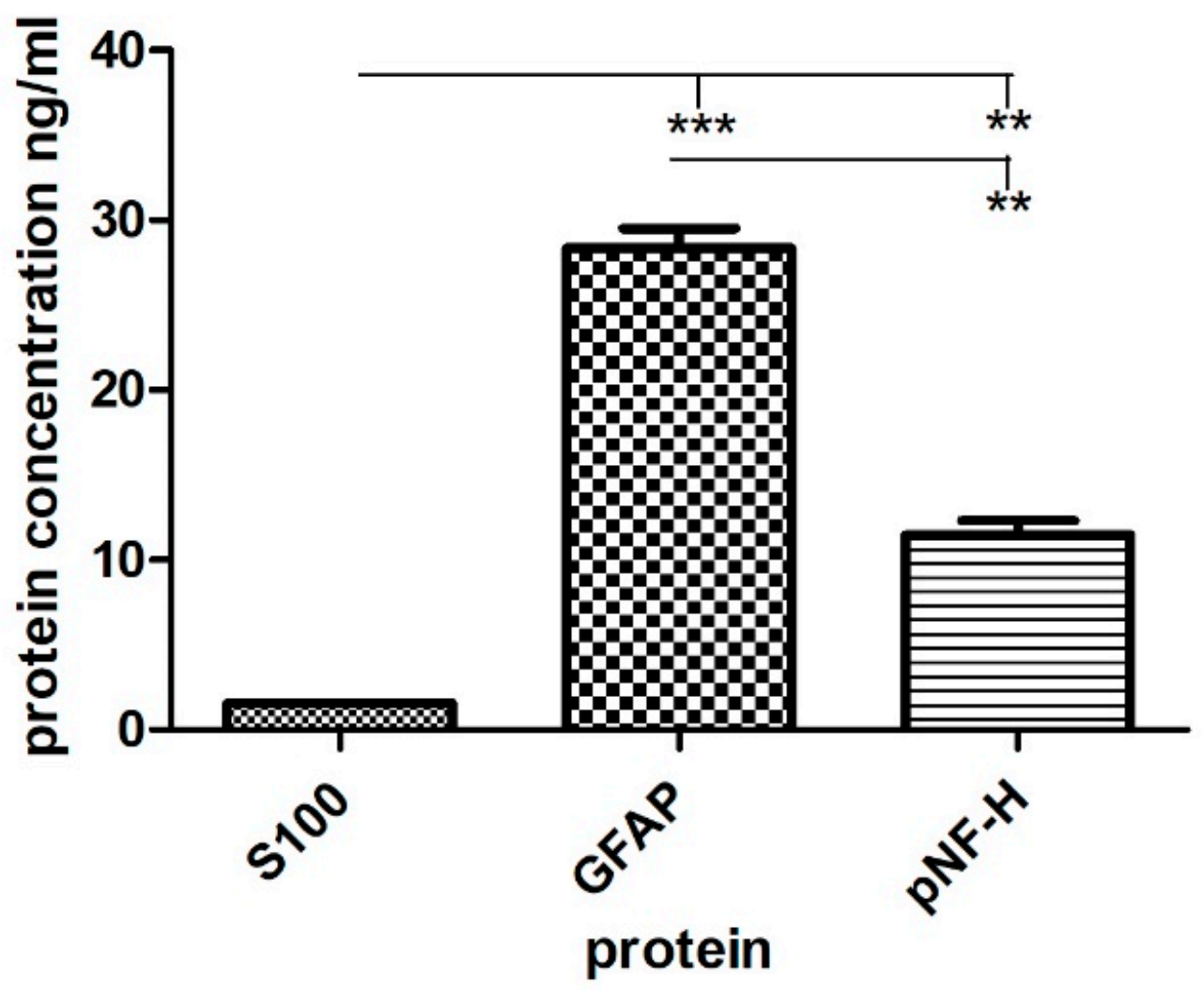

Figure 4. The levels of S100, GFAP, and pNF-H protein in the CSF of an SCI patient treated with autologous BM-MSCs. Protein values are obtained from CSF on the day of BM-MSCs application. The presence of glial cell proteins predominates over neuronal cell proteins. Data are shown as the mean $\pm \mathrm{SD},{ }^{* *} p<0.01,{ }^{* * *} p<0.001$. DaI-Days after Injury.

SCI caused an increase in interleukin IL-10 levels by almost 2-fold when compared to healthy controls (IL-10 $=2.72 \pm 0.40 \mathrm{pg} / \mathrm{mL}$ at $14 \mathrm{DaI}$ vs. controls $=1.45 \pm 0.51 \mathrm{pg} / \mathrm{mL}$, Figure 5A). IL-10 is a well-known anti-inflammatory cytokine. In addition to inhibiting the synthesis and release of pro-inflammatory mediators, it has been shown, that IL-10 exerts neuroprotective effects directly to neurons by suppressing cell death mechanisms due to the reduction of apoptosis. Furthermore, IL-10 plays a role in the activation of several signaling cascades involved in the survival and growth of spinal cord neurons in in vitro studies [62-64]. In vivo studies have been shown the positive effect of IL-10 in a reduction of secondary inflammatory [65]. IL-10 with IL-4 are preliminarily adopted as serologic markers to forecast SCI, and high serum levels of IL-4 and IL-10 may indicate a better prognosis [66]. We can see a similar response to injury in the expression of IL-1 receptor antagonist (IL-1Ra) protein, where protein levels within two weeks after injury slightly increased when compared to control levels (Figure 5B). IL-1Ra is an inhibitor of the pro-inflammatory effect of IL-1 $\beta$. IL-1Ra with anti-inflammatory properties is secreted by various types of cells [67]. BM-MSCs treatment significantly increased the production of the anti-inflammatory cytokines IL-10 and IL-Ra at 18 DaMSC in comparison with the levels at 14 DaI before the treatment (IL-10 $=9.61 \pm 0.52 \mathrm{pg} / \mathrm{mL}$ at 18 DaMSC vs. $2.72 \pm 0.40 \mathrm{pg} / \mathrm{mL}$ at $14 \mathrm{DaI}, p<0.05, \mathrm{IL}-1 \mathrm{Ra}=33 \pm 2.55 \mathrm{pg} / \mathrm{mL}$ at $18 \mathrm{DaMSC}$ vs. $7.37 \pm 0.79 \mathrm{pg} / \mathrm{mL}$ at $14 \mathrm{DaI}$, $p<0.001)$. Six months after BM-MSCs application, both cytokines retained significantly high serum levels with a tendency to increase over time when compared to control values. 
A

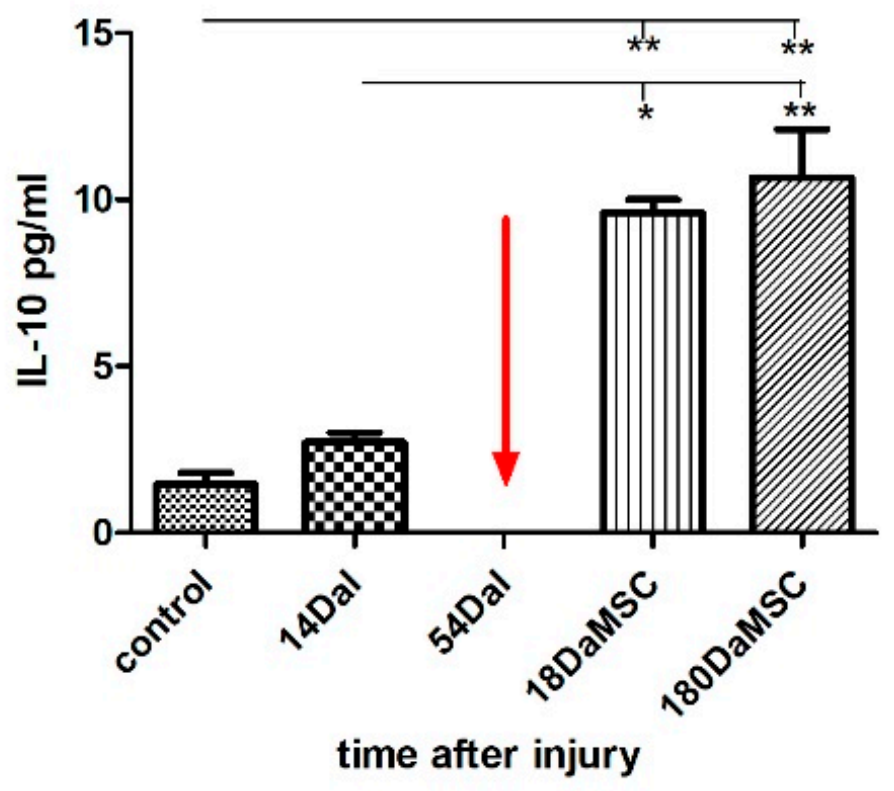

C

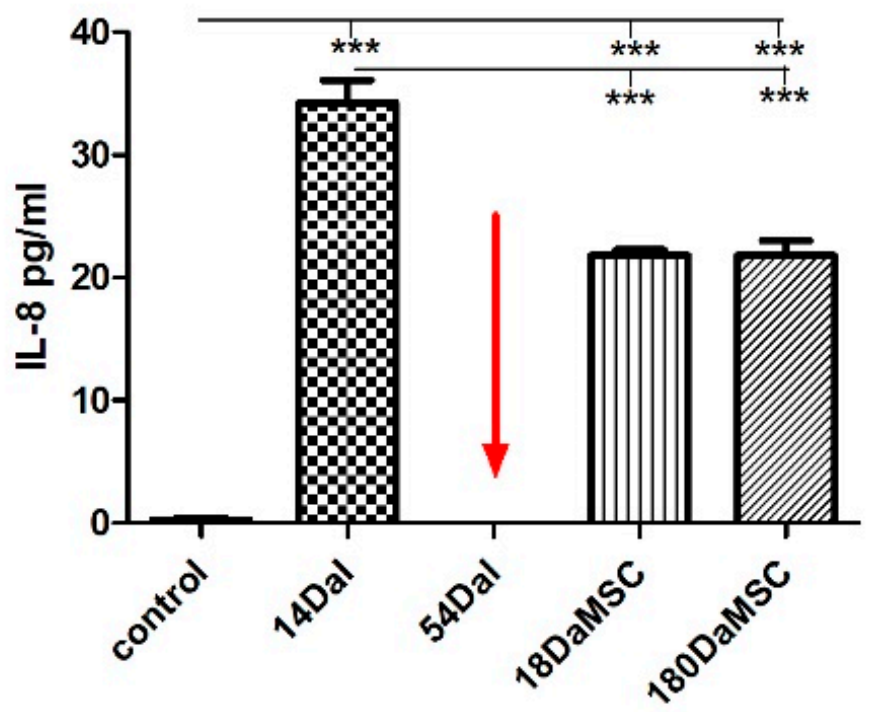

B

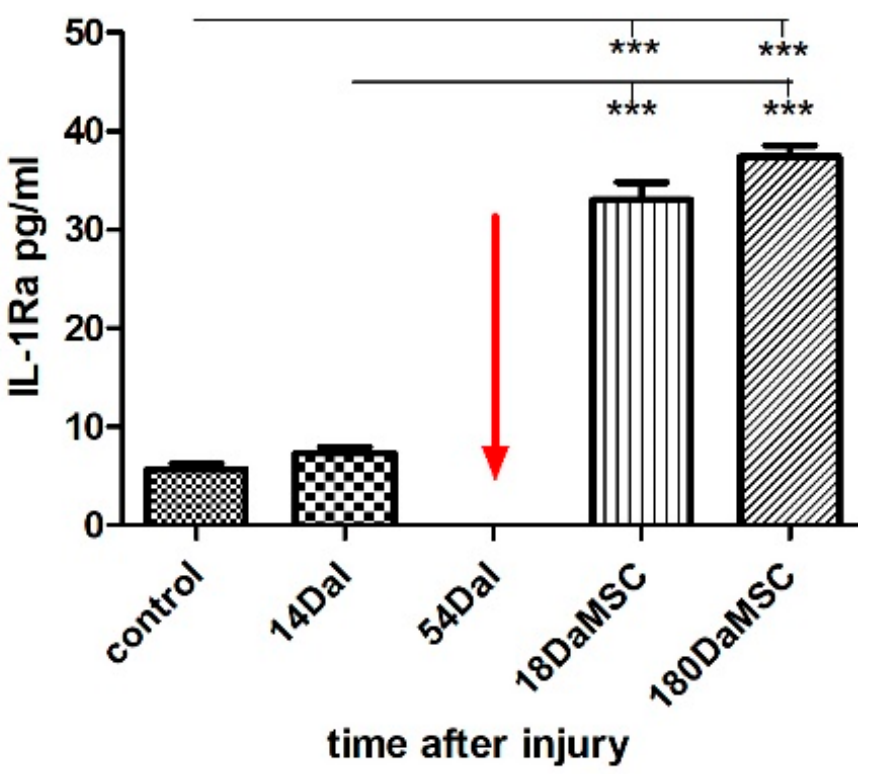

time after injury

Figure 5. Influence of autologous BM-MSCs treatment on cytokine concentrations in the serum of an SCI patient. Levels of the cytokines IL-10 and IL-1Ra were significantly increased after BM-MSCs application at 18 DaMSC in comparison with their levels before the treatment $(\mathbf{A}, \mathbf{B})$. The level of IL-8 was significantly reduced at 18 DaMSC and 180 DaMSC due to BM-MSCs administration when compared with its level at $14 \mathrm{DaI}$ before the treatment $(\mathbf{C})$. The red arrow indicates the administration time of autologous BM-MSCs. Data are shown as the mean $\pm \mathrm{SD},{ }^{*} p<0.05,{ }^{* *} p<0.01,{ }^{* * *} p<0.001$. DaI-Days after Injury, DaMSC—Days after BM-MSCs transplantation. 
In contrast, interleukin IL-8 behaved in the opposite way to IL-10 and IL-1Ra cytokines (Figure 5C). IL-8 is a chemoattractant cytokine with a distinct target specificity for the neutrophil and is produced by a variety of tissues and blood cells [68]. IL-8 also supports cell homing and angiogenesis due to the expression of 41 core proteins in BM-MSCs through the PI3K/Akt pathway, which could promote the proliferation and migration of vascular endothelial cells [69]. In our study there was a significantly increase of IL-8 levels in the serum at $14 \mathrm{DaI}$ when compared to controls of healthy individuals (IL-8 $=34.25 \pm 2.62 \mathrm{pg} / \mathrm{mL}$ vs. controls $=0.3 \pm 0.22 \mathrm{pg} / \mathrm{mL}, p<0.001)$. The production of IL-8 was significantly decreased during the first two weeks after the BM-MSCs therapy at 18 DaMSC $(p<0.001)$ in comparison with its levels before the BM-MSCs application at 14 DaI. However, with increasing time after BM-MSCs administration, IL-8 did not tend to increase its expression in the serum of a BM-MSCs treated patient.

Similarly, as we observed in cytokines levels, the interferon-gamma inducible protein of $10 \mathrm{kDa}$ (IP-10), monocyte chemoattractant protein-1 (MCP-1) and Eotaxin display significantly high expression during $14 \mathrm{DaI}$ with 10-20 times higher levels when compared to control values $(\mathrm{IP}-10=468.10 \pm 7.21 \mathrm{pg} / \mathrm{mL}$ at $14 \mathrm{DaI}$ vs. controls $=45.25 \pm 7.26 \mathrm{pg} / \mathrm{mL}$, $\mathrm{MCP}-1=780.66 \pm 8.40 \mathrm{pg} / \mathrm{mL}$ at $14 \mathrm{DaI}$ vs. controls $=30.28 \pm 5.03 \mathrm{pg} / \mathrm{mL}$, Eotaxin $=207.43 \pm 10.51 \mathrm{pg} / \mathrm{mL}$ at $14 \mathrm{DaI}$ vs. controls $=23.17 \pm 4.07 \mathrm{pg} / \mathrm{mL}, p<0.001$, Figure $6 \mathrm{~A}-\mathrm{C}$ ). In the case of regulated upon activation, normal $\mathrm{T}$ cell expressed and presumably secreted (RANTES), there is an almost 50-fold significant increase in the serum level of this protein in comparison with the control of healthy individuals (RANTES $=2002.76 \pm 55.92 \mathrm{pg} / \mathrm{mL}$ at $14 \mathrm{DaI}$ vs. controls $=41.75 \pm 20.58 \mathrm{pg} / \mathrm{mL}, p<0.001$ ) (Figure 6D). Administration of BM-MSC caused a significant decrease $(p<0.001)$ in the level of IP-10 protein at 18 DaMSC in comparison with its level after injury at $14 \mathrm{DaI}$ with a tendency to maintain a similarly low level within a six-month follow-up period after the cell administration. IP-10 is a smallinducible cytokine secreted during the inflammation by various cell types and acts as a potent inducer of apoptosis not only in infectious diseases but also during the development of the nervous system [70]. IP-10 is normally expressed in the spinal cord at low levels, but upon stimulation, the expression of this chemokine is significantly increased at glial cell accumulation sites [71]. IP-10 is also involved in neuronal injury and inflammation, where together with other glial chemokines, MCP-1 and RANTES, recruits leukocytes into inflammatory sites after CNS injury [72]. Interestingly, proteins IP-10 and IL-10 are interrelated; even in a previous study it was observed that IP-10 induces the production of IL-10 [73]. The significant decrease in the expression also occurred in the serum level of RANTES after BM-MSCs application at 18 DaMSC $(p<0.05)$ in comparison with its level after injury at $14 \mathrm{DaI}$. Based on our results, the RANTES protein tended to increase its level in response to BM-MSCs application. Similar results were obtained in other studies, where the expression of Ccl2/MCP-1 and Ccl5/RANTES was enhanced after MSCs transplantation and locomotor activity after spinal cord transection in mice was improved [74]. In the levels of the Eotaxin and MCP-1 proteins, we observed a similar pattern of changes in their serum levels after BM-MSCs application. Eotaxin is an eosinophil-selective chemokine, which recruits eosinophils during inflammatory conditions and plays a role in a variety of pathologic conditions [75]. Eotaxin and MCP-1 proteins maintained their high levels of 18 DaMSCs. However, after long-term follow-up, we observed a declining trend in the levels of these proteins. This finding can be explained by the fact that the chemokines RANTES and MCP-1, in addition to their chemotactic role, according to some published works, also play an important role in axonal regeneration and neuroprotection [76-78].

\subsection{BM-MSCs Treatment Changed the Serum Levels of Growth Factors after SCI}

In our study, we also monitored the changes in the expression of four growth factors in the serum (epidermal growth factor (EGF), vascular endothelial growth factor (VEGF), basic fibroblast growth factor (FGF-2), and platelet-derived growth factor (PDGF-AB/BB)) during the BM-MSCs treatment of SCI. 
Two weeks after the injury, we recorded significantly higher levels of PDGF-AB/BB, VEGF, and EGF in the patient's serum compared with the control levels $(p<0.001)$ (Figure 7). Administration of autologous BM-MSCs caused a significant increase in levels of PDGF$\mathrm{AB} / \mathrm{BB}$ proteins at 18 DaMSC $(p<0.001)$. BM-MSCs application also caused an increase in FGF-2 and VEGF levels at 18 DaMSC, but not significantly. However, a significant increase in FGF-2 $(p<0.05)$ and VEGF $(p<0.01)$ occurred after a longer period after BMMSC s application, at 180 DaMSC. VEGF is well-known as a specific mitogen promoting the growth and development of vascular endothelial cells. In combination with FGF2 induces therapeutic angiogenesis [34]. Except, it is well established that VEGF is a potent angiogenic factor and that VEGF also plays a crucial role in the neurotrophic and neuroprotective activity in neurons, leading to increased axonal outgrowth in the nervous system. Furthermore, in vitro studies revealed that VEGF is a positive effector for growth cone movement and led to a considerable increase in dorsal root ganglia growth cone size [79-81]. VEGF may play an important role in neuroprotection as a therapeutic agent after acute traumatic SCI [82]. FGF-2 is widely known as an important player in wound healing for its proangiogenic effects. In addition to stimulating angiogenesis, FGF-2 improves neural cell growth and performs an important role in neurodegenerative diseases of the peripheral nervous system. In summary, its neurotrophic and angiogenic properties have a positive impact on the regeneration process [83]. As we can see from the measured values, the expression levels of FGF-2 and VEGF are interrelated. Not only does a combination of VEGF-A and FGF-2 have a strong synergistic effect on the new vessel formation in both in vivo and in vitro experimental conditions, even a combination of three growth factors FGF-2, VEGF-A, and PDGF-Ab/BB has a strong synergistic effect on the induction of neovascularization in experimental animal models in vivo [83]. Our results also reflect that all three factors have a similar course of the increase in the serum after administration of BM-MSCs. In contrast, the production of EGF protein was significantly reduced during the first 18 days after BM-MSCs application when compared with its level before BM-MSCs treatment at $14 \mathrm{DaI}(p<0.001)$. However, after 6 months follow-up, the production of EGF protein tended to increase. SCI causes glial cells adjacent to the lesion to significantly alter their phenotypes and activities. EGF seems to play a decisive role in this process by conversion of astrocytes to their reactive form [84]. MSCs themselves produce anti-inflammatory cytokines and growth factors, as well as stimulate their production in other cells, which thus also participate in the subsequent regeneration of damaged tissue. MSCs can improve astrogliosis by inhibition of the EGF receptor and ultimately upgrade the regeneration after SCI [85].

In summary, in this study, we compared the levels of multiple cytokines, chemokines, growth factors, and so-called neuromarkers in the serum of an SCI patient before and after the treatment with autologous BM-MSCs. This study established two main points: (a) the effect of autologous BM-MSCs administration after SCI on the levels of cytokines/chemokines/growth factors (EGF, Eotaxin, FGF-2, IL-10, IL-1Ra, IL-8, IP-10, MCP-1, PDGF$\mathrm{AB} / \mathrm{BB}, \mathrm{RANTES}, \mathrm{VEGF}$ ) in the serum of an SCI patient, (b) the ability to detect the presence and the level status of SCI neuromarkers (S100, GFAP, and pNF-H proteins) in the serum and cerebrospinal fluid of an SCI patient treated with autologous BM-MSCs.

Our preliminary results demonstrate that SCI, as well as subsequent BM-MSCs therapy, caused significant changes mainly in the levels of growth factors and neuromarkers detected in the serum. The most significant changes occurred in the serum levels of the neuromarkers GFAP, S100 as well as the growth factors FGF-2, PDGF-AB/BB, and VEGF when compared to the levels before and after the treatment.

In summary, these findings demonstrate that neurodegenerative processes after traumatic SCI can be quantified biochemically by measuring S100, GFAP, and pNF-H levels in the serum or CSF. Together with inflammatory cytokines, growth factors and other biomolecules could emerge as surrogate markers and secondary outcome measures for neurodegenerative processes as well as for the rapid determination as to whether the 
patient was improving, worsening, or showed sustained neurological stability in response to the current treatment.

A

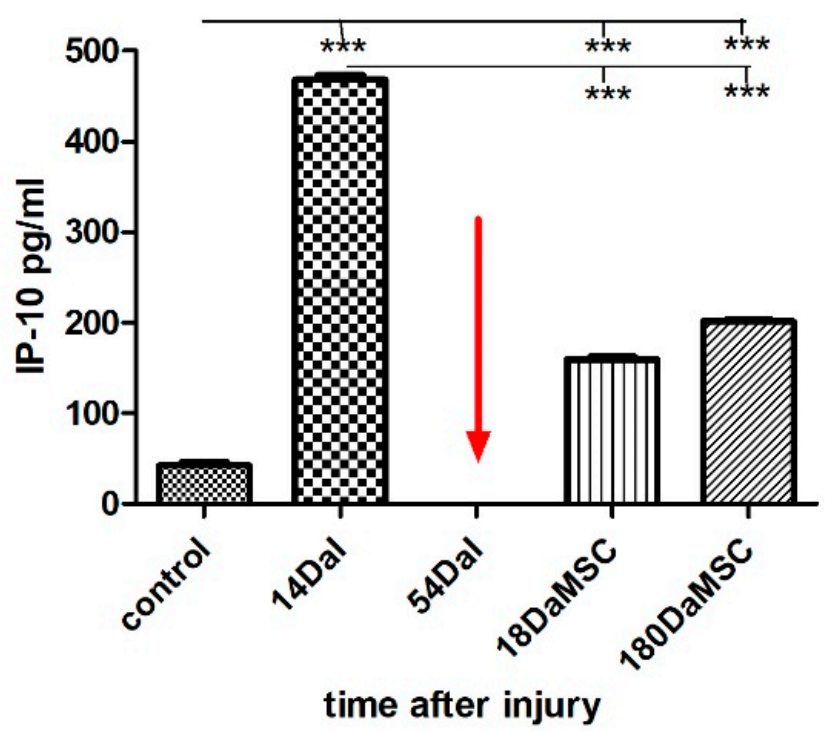

C

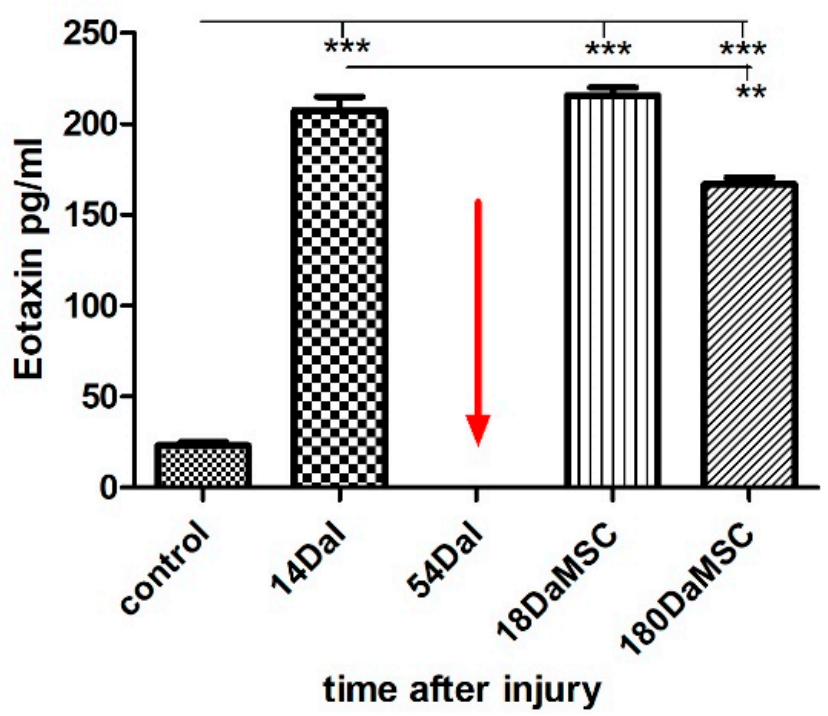

B

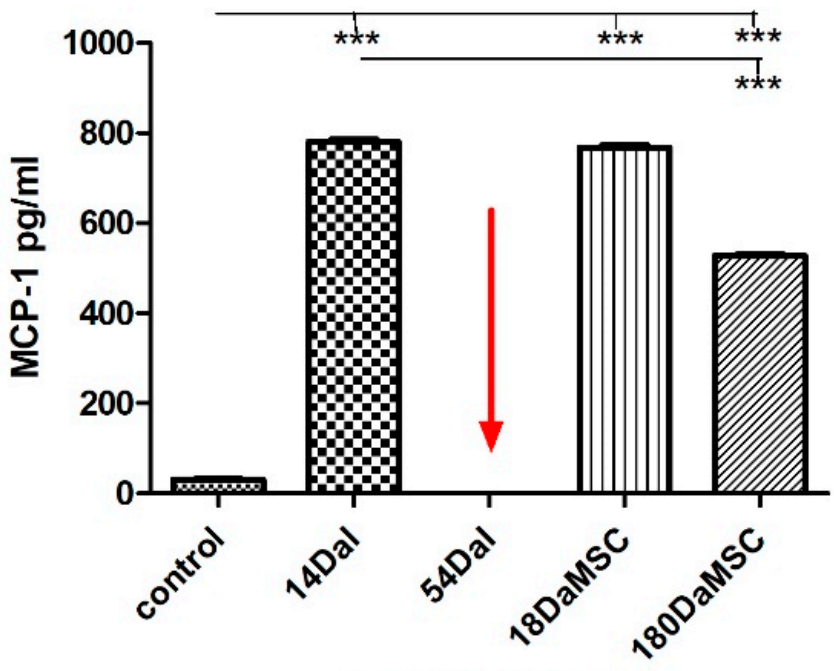

time after injury

D

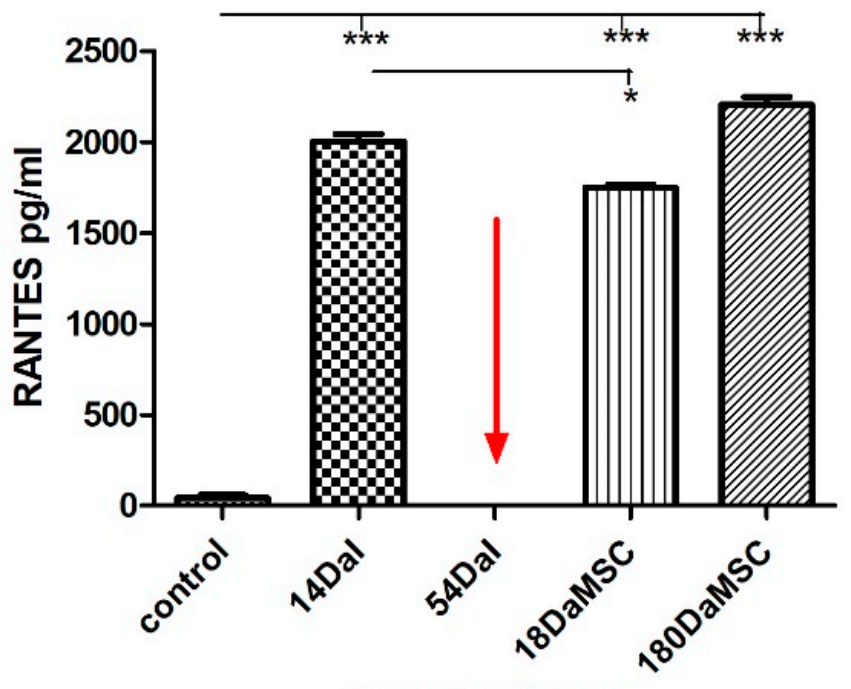

time after injury

Figure 6. An overview of the level of the chemokine proteins in the serum of an SCI patient treated with autologous BM-MSCs. SCI caused a significant increase in IP-10 (A), MCP-1 (B), Eotaxin (C), and RANTES (D) protein levels in the patient's serum at $14 \mathrm{DaI}$ in comparison with controls. Administration of autologous BM-MSCs at day 54 post-injury resulted in a significant decrease in the levels of IP-10 and RANTES proteins at 18 DaMSC (A,D). The red arrow indicates the administration time of autologous BM-MSCs. Data are shown as the mean $\pm \mathrm{SD},{ }^{*} p<0.05,{ }^{* *} p<0.01,{ }^{* * *} p<0.001$. DaI-Days after Injury, DaMSC—Days after BM-MSCs transplantation. 
A

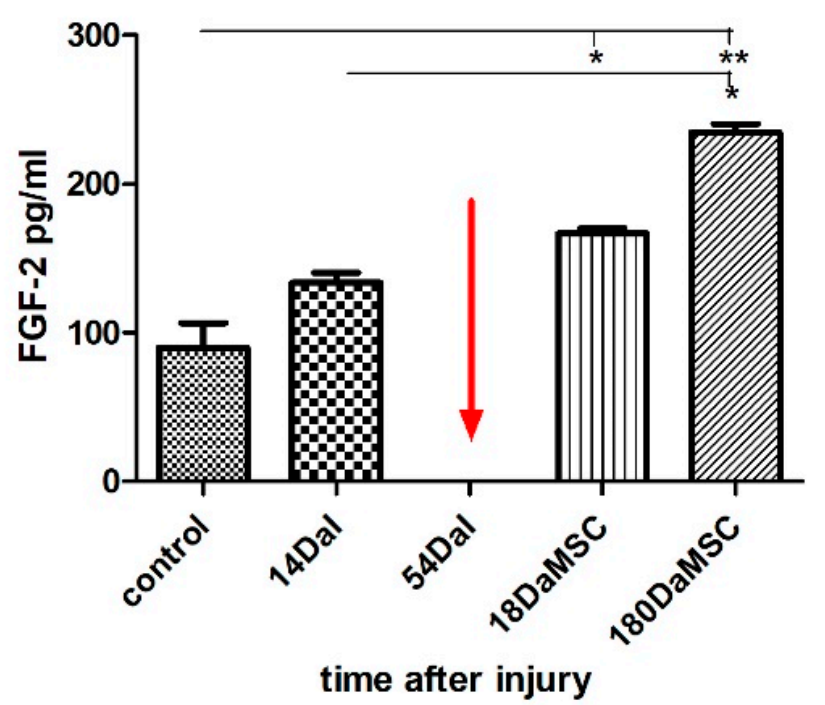

C

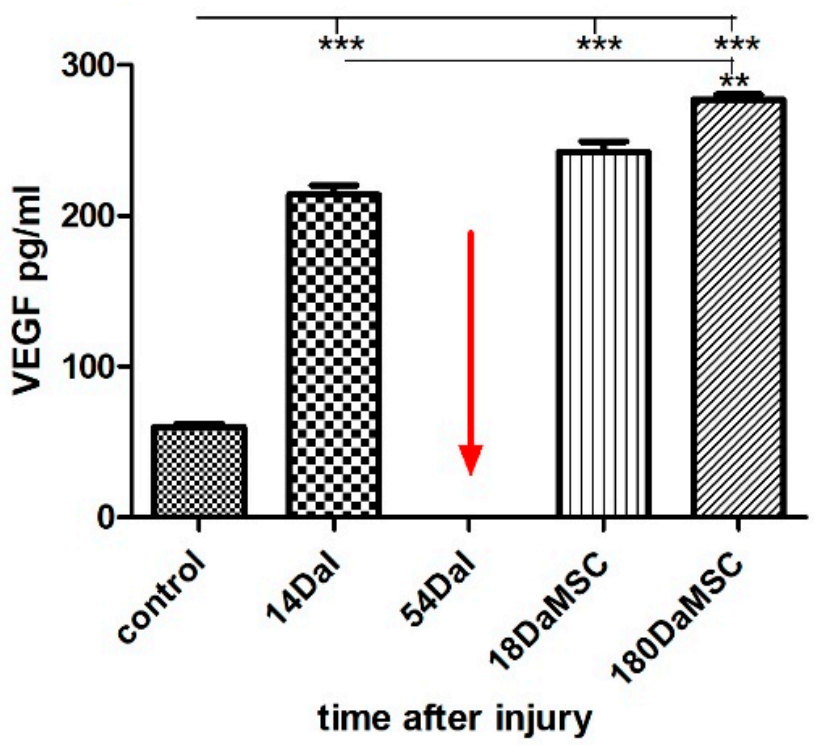

B

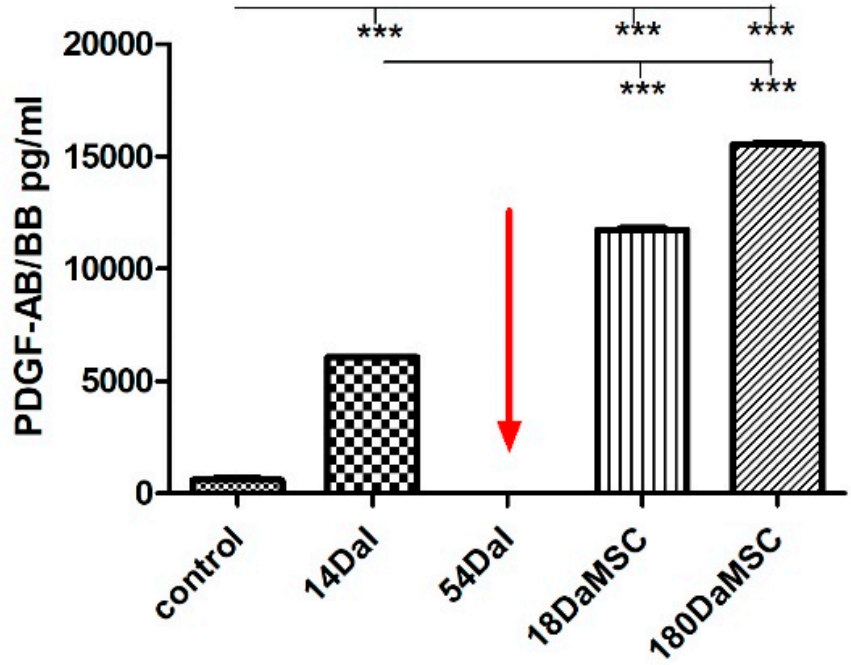

time after injury

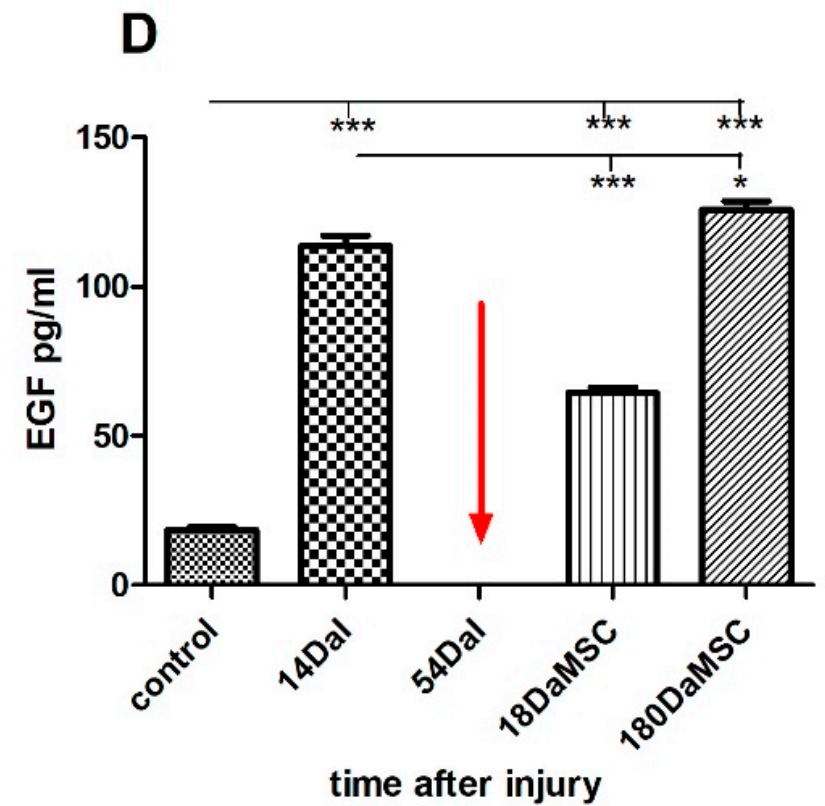

Figure 7. An overview of the level of the growth factors in the serum of an SCI patient treated with autologous BM-MSCs. Fourteen days after the injury, we recorded significantly higher levels of PDGF-AB/BB (B), VEGF (C), and EGF (D) in the patient's serum when compared with control levels. FGF-2 protein levels also increased after SCI, but not significantly (A). BM-MSCs application showed a significant increase in FGF-2, PDGF-AB/BB, and VEGF levels. Conversely, there was a significant decrease in EGF protein expression after the application of autologous BM-MSCs at 18 DaMSC in comparison with its level before BM-MSCs treatment at $14 \mathrm{DaI}$ (D). The red arrow indicates the administration time of autologous BM-MSCs. Data are shown as the mean $\pm \mathrm{SD}, * p<0.05,{ }^{* *} p<0.01$, $* * * p<0.001$. DaI-Days after Injury, DaMSC—Days after BM-MSCs transplantation.

Despite these very promising results, we acknowledge that the suitability of selected markers for SCI and the efficacy of BM-MSCs therapy after SCI have to be confirmed on a large group of patients in randomized clinical trials. 


\section{Material and Methods}

\subsection{Patient Enrolment}

A 35-year-old male with acute SCI and paraplegia after a bicycle accident, injured at the thoracic T6 level, was enrolled in our Department of Trauma Surgery. This study was approved by the institutional Ethics Committee of L. Pasteur University Hospital (06/EK/2020). Ethical guideline provisions from the Helsinki Declaration were followed. Written informed consent and the baseline status were obtained from all subjects before the study.

\subsection{Bone Marrow Collection and MSCs Isolation}

The BM was collected in the operating room under the general narcosis. BM was aspirated aseptically from the iliac crest. BM aspirates were combined with a $5 \%(v / v)$ Heparin anticoagulant (Becton Dickinson, San Jose, CA, USA) in the syringe to prevent coagulation. Directly after BM aspiration, all tubes were gently mixed and immediately $(<1 \mathrm{~h})$ transported on ice to the Associated Tissue Bank, Faculty of Medicine of P. J. Safarik University and L. Pasteur University Hospital. All cell manufacturing procedures were performed under strict sterile conditions. In the laboratory, BM aspirates were directly processed for the MSCs extraction using the red blood cell lysis method. Erythrocyte lysis buffer $\left(10 \times\right.$ stock solution: ultrapure water with $1.5 \mathrm{M}$ ammonium chloride $\left(\mathrm{NH}_{4} \mathrm{Cl}\right)$, $100 \mathrm{mM}$ potassium bicarbonate $\left(\mathrm{KHCO}_{3}\right), 1 \mathrm{mM}$ ethylenediaminetetraacetic acid (EDTA) (all from Sigma-Aldrich, Merck KGaA, Darmstadt, Germany) was added to the total volume of BM in the proportion 1:4 (BM volume: 1 x lysis buffer). The conical centrifugal tube was mixed manually for $10 \mathrm{~min}$ on ice and centrifuged at $200 \times g$ for $10 \mathrm{~min}$ at $4{ }^{\circ} \mathrm{C}$. Promptly, after centrifugation, the supernatant was discarded and the pellet was resuspended in Dulbecco's Modified Eagle's Medium (DMEM; Gibco; Thermo Fisher Scientific, Inc., Waltham, MA, USA) and washed twice using centrifugation in the same conditions ( $10 \mathrm{~min}$ at $\left.200 \times g, 4^{\circ} \mathrm{C}\right)$. Total cell number was determined by using a Bürker cell counting chamber. Finally, mononuclear cells were seeded at a density $1 \times 10^{6}$ cells $/ \mathrm{cm}^{2}$ in $75 \mathrm{~cm}^{2}$ ventilated tissue culture treated flasks and cultivated in the complete cultivation medium containing alpha-modified minimum essential medium ( $\alpha$-MEM) supplemented with $10 \%$ fetal bovine serum (FBS) and 1\% ( $v / v)$ antibiotic/antimycotic solution (all from Gibco, Thermo Fisher Scientific, Inc., Waltham, MA, USA). After initial incubation for 2-3 days, the flasks were carefully washed to remove nonadherent cells and the medium was replaced with a fresh culture medium. The cultures were maintained in a humidified incubator at $37^{\circ} \mathrm{C}$ with $5 \% \mathrm{CO}_{2}$ and the medium was changed twice a week. The pathogenand virus-free status was confirmed according to the safety analysis such as sterility, mycoplasma, and endotoxin detection before transplantation. In addition, tri-lineage differentiation tests in vitro and phenotypic control of BM-MSCs at 0 passages were used in this clinical study. The final product was prepared as $4.08 \times 10^{6}$ cell/dose of autologous BM-MSCs with $92.8 \%$ of viability. The cell viability was evaluated with trypan blue staining.

\subsection{Phenotypic Analysis of BM-MSCs before Application}

Before application, immunophenotypic analysis of BM-MSCs was performed with a human MSC phenotyping kit (Miltenyi Biotec, Bergisch Gladbach, Germany). A minimum of $2 \times 10^{5}$ cells were resuspended in PBS (Sigma-Aldrich, Merck KGaA, Darmstadt, Germany) with $2 \%$ FBS (FBS, Thermo Fisher Scientific, Inc., Waltham, MA, USA), centrifuged at $300 \times g$ for $10 \mathrm{~min}$, stained with a cocktail of antibodies CD 45 FITC, CD 90 FITC, CD 105 PE, CD 73 APC for 10 min in dark, washed with PBS containing 2\% FBS and centrifuged at $300 \times g$ for $10 \mathrm{~min}$. Cells were analyzed with a Becton Dickinson FACSCalibur using CellQuestPro software (Becton Dickinson, San Jose, CA, USA).

\subsection{Preparation of BM-MSCs for Clinical Application}

Two weeks before application, the FBS was changed to the patient's autologous serum during cultivation. After reaching a confluence of above $90 \%$ (4-5 weeks from initial 
seeding), cells from passage 0 were washed twice with sterile PBS and treated with $0.25 \%$ Trypsin-EDTA solution (Gibco; Thermo Fisher Scientific, Inc., Waltham, MA, USA) for $2 \mathrm{~min}$ at $37^{\circ} \mathrm{C}$. Cells solution was collected and centrifuged at $200 \times \mathrm{g}$ for $10 \mathrm{~min}$ at $4{ }^{\circ} \mathrm{C}$. The total number of cells was counted after discarding the supernatant. Before application, the cell pellet was resuspended in sterile $0.9 \%$ saline solution in a final volume of $1 \mathrm{~mL}$. For transportation, BM-MSCs in sterile normal saline were maintained in a temperaturecontrolled environment of approximately $4{ }^{\circ} \mathrm{C}$ under sterile and dark conditions. The stem cells suspension was transported as rapidly as possible.

\subsection{BM-MSCs Administration}

The transplantation of BM-MSCs $\left(4.08 \times 10^{6} / \mathrm{mL}\right)$ was performed by intrathecal injection in the operating theater under general anesthesia. The surgical wound was closed in a regular manner. The transplantation was performed using freshly harvested cells on 54 DaI.

\subsection{Sample Collection \\ 3.6.1. Serum}

Whole blood was collected in a covered test tube without anticoagulants and the clot was then removed by centrifuging at $1500 \times g$ for $10 \mathrm{~min}$. Serum samples were collected at given time points (Figure 8 ). Controls were presented by healthy individuals of the same age and gender as the patient $(n=3)$. After centrifugation, human serum was aliquoted and stored at $-80{ }^{\circ} \mathrm{C}$ until detection.

$\begin{array}{llllll}\text { Days of blood collection } & 14 \mathrm{DaI} & 29 \mathrm{DaI} & 48 \mathrm{DaI} & 18 \mathrm{DaMSC} & 180 \mathrm{DaMSC}\end{array}$

Figure 8. Time points of blood collection. Note: DaI-Days after Injury; DaMSC—Days after BM-MSC transplantation.

\subsubsection{Cerebrospinal Fluid}

To minimize the number of invasive procedures to the injured patient, CSF was obtained during the same procedure as the BM-MSCs were administered intrathecally on $54 \mathrm{DaI}$, in the quantity of $5 \mathrm{~mL}$. Collected CSF was separated by centrifugation at $300 \times g$ for $10 \mathrm{~min}$ to remove any cells or large cellular fragments, aliquoted, and stored at $-80{ }^{\circ} \mathrm{C}$ until detection.

\subsection{Multiplex Assay for Analysis of Cytokine/Chemokine/Growth Factors}

Concentrations of 11 analytes (EGF, FGF-2, IL-10, IL-8, IL-1Ra, IP-10, MCP-1, Eotaxin, PDGF-AB/BB, RANTES, VEGF) were quantified by a triplicate for each serum sample/time point using MILLIPLEX ${ }^{\circledR}$ Assays (Millipore, Merck KGaA, Darmstadt, Germany) to determine the mean of fluorescence intensity (MFI) values according to the manufacturer's protocol and the MAGPIX Luminex platform. xPONENT software version 4.2 for MAGPIX (Luminex Corporation, Austin, TX, USA) and Bio-Plex Manager 6.1 (Bio-Rad Laboratories, Hercules, CA, USA) were used for data analysis. After creating a standard curve, concentrations were interpolated for each sample and expressed as $\mathrm{pg} / \mathrm{mL}$.

\subsection{ELISA Measurement of Human S100, GFAP, and pNF-H}

The concentrations of target proteins in the serum and the CSF of the patient were detected using the Human S100, GFAP, and Phosphorylated Neurofilament H (pNF-H) Kits (all from Millipore, Merck KGaA, Darmstadt, Germany), following the manufacturer's protocols. Samples were added into the wells of a polystyrene plate with pre-coated monoclonal antibodies against the specific protein of our interest and washed out with wash buffer after their respective additions to the wells. TMB substrate was used for coloration after the enzyme conjugate had already been thoroughly washed out of the wells. TMB reacted to form a blue product from the peroxidase activity and finally turned yellow after the addition of the stop solution. The optical density value of the target analyte 
in the sample was assessed at $450 \mathrm{~nm}$ using a microplate reader (TriStar LB941, Berthold Technologies, Bad Wildbad, Germany). Then, the standard curve was generated and the protein levels of tested samples were calculated according to the manufacturer's guidance.

\subsection{Statistical Analysis}

Statistical differences among the groups were assessed by one-way ANOVA and Dunn's multiple comparison test as post hoc analysis using GraphPad Prism software (GraphPad Prism Software, Inc.). Values $p<0.05$ were considered statistically significant ${ }^{*} p$-value of $<0.05,{ }^{* *} p$-value of $<0.01,{ }^{* * *} p$-value of $\left.<0.001\right)$. The concentrations of proteins were expressed as the mean \pm standard deviation (SD).

Author Contributions: Methodology, D.H., J.M. and J.J.; cell preparation, T.S.; cell application, P.C.; analysis, M.M. and L.S.; writing—original draft preparation, L.S.; writing—review and editing, T.S.; supervision, J.R. All authors have read and agreed to the published version of the manuscript.

Funding: This work was supported by the project: „Open scientific community for modern interdisciplinary research in medicine (OPENMED), ITMS2014+: 313011 V455 supported by the Operational Programme Integrated Infrastructure, funded by the ERDF. This research was also supported by the Slovak Research and Development Agency under the contract No. APVV-17-0118.

Institutional Review Board Statement: The study was conducted in accordance with the Declaration of Helsinki, and approved by the Ethics Committee of L. Pasteur University Hospital, Kosice, Slovakia (Approval ID 06/EK/2020).

Informed Consent Statement: Informed consent was obtained from all subjects involved in the study.

Data Availability Statement: The study did not report any data.

Conflicts of Interest: The authors declare no conflict of interest.

\section{References}

1. Grégoire, C.-A.; Goldenstein, B.L.; Floriddia, E.M.; Barnabé-Heider, F.; Fernandes, K.J.L. Endogenous neural stem cell responses to stroke and spinal cord injury. Glia 2015, 63, 1469-1482. [CrossRef] [PubMed]

2. Dumont, R.J.; Okonkwo, D.O.; Verma, S.; Hurlbert, R.J.; Boulos, P.T.; Ellegala, D.B.; Dumont, A.S. Acute Spinal Cord Injury, Part I: Pathophysiologic Mechanisms. Clin. Neuropharmacol. 2001, 24, 254-264. [CrossRef] [PubMed]

3. Yang, T.; Dai, Y.; Chen, G.; Cui, S. Dissecting the Dual Role of the Glial Scar and Scar-Forming Astrocytes in Spinal Cord Injury. Front. Cell. Neurosci. 2020, 14, 78. [CrossRef]

4. Hagg, T.; Oudega, M. Degenerative and Spontaneous Regenerative Processes after Spinal Cord Injury. J. Neurotrauma 2006, 23, 263-280. [CrossRef] [PubMed]

5. Rowland, J.W.; Hawryluk, G.W.J.; Kwon, B.; Fehlings, M.G. Current status of acute spinal cord injury pathophysiology and emerging therapies: Promise on the horizon. Neurosurg. Focus 2008, 25, E2. [CrossRef]

6. Lu, P.; Dulin, J.N. Bridging the injured spinal cord with neural stem cells. Neural Regen. Res. 2014, 9, 229-231. [CrossRef]

7. Levi, A.D.; Anderson, K.D.; Okonkwo, D.O.; Park, P.; Bryce, T.N.; Kurpad, S.N.; Aarabi, B.; Hsieh, J.; Gant, K. Clinical Outcomes from a Multi-Center Study of Human Neural Stem Cell Transplantation in Chronic Cervical Spinal Cord Injury. J. Neurotrauma 2019, 36, 891-902. [CrossRef]

8. Lu, P.; Wang, Y.; Graham, L.; McHale, K.; Gao, M.; Wu, D.; Brock, J.; Blesch, A.; Rosenzweig, E.; Havton, L.A.; et al. Long-Distance Growth and Connectivity of Neural Stem Cells after Severe Spinal Cord Injury. Cell 2012, 150, 1264-1273. [CrossRef]

9. Kanno, H.; Pearse, D.D.; Ozawa, H.; Itoi, E.; Bunge, M.B. Schwann cell transplantation for spinal cord injury repair: Its significant therapeutic potential and prospectus. Rev. Neurosci. 2015, 26, 121-128. [CrossRef]

10. Tan, C.; Yang, C.; Liu, H.; Tang, C.; Huang, S. Effect of Schwann cell transplantation combined with electroacupuncture on axonal regeneration and remyelination in rats with spinal cord injury. Anat. Rec. Adv. Integr. Anat. Evol. Biol. 2021, 304, 2506-2520. [CrossRef]

11. Raisman, G.; Carlstedt, T.; Choi, D.; Li, Y. Clinical prospects for transplantation of OECs in the repair of brachial and lumbosacral plexus injuries: Opening a door. Exp. Neurol. 2011, 229, 168-173. [CrossRef] [PubMed]

12. Sun, Y.; Xu, C.-C.; Li, J.; Guan, X.-Y.; Gao, L.; Ma, L.-X.; Li, R.-X.; Peng, Y.-W.; Zhu, G.-P. Transplantation of Oligodendrocyte Precursor Cells Improves Locomotion Deficits in Rats with Spinal Cord Irradiation Injury. PLoS ONE 2013, 8, e57534. [CrossRef] [PubMed]

13. Wu, B.; Sun, L.; Li, P.; Tian, M.; Luo, Y.; Ren, X. Transplantation of oligodendrocyte precursor cells improves myelination and promotes functional recovery after spinal cord injury. Injury 2012, 43, 794-801. [CrossRef] [PubMed] 
14. Tetzlaff, W.; Okon, E.; Karimi-Abdolrezaee, S.; Hill, C.E.; Sparling, J.; Plemel, J.; Plunet, W.T.; Tsai, E.; Baptiste, D.; Smithson, L.J.; et al. A Systematic Review of Cellular Transplantation Therapies for Spinal Cord Injury. J. Neurotrauma 2011, 28, 1611-1682. [CrossRef]

15. Dominici, M.; Le Blanc, K.; Mueller, I.; Slaper-Cortenbach, I.; Marini, F.C.; Krause, D.S.; Deans, R.J.; Keating, A.; Prockop, D.J.; Horwitz, E.M. Minimal criteria for defining multipotent mesenchymal stromal cells. The International Society for Cellular Therapy position statement. Cytotherapy 2006, 8, 315-317. [CrossRef]

16. DiGirolamo, C.M.; Stokes, D.; Colter, D.; Phinney, D.; Class, R.; Prockop, D.J. Propagation and senescence of human marrow stromal cells in culture: A simple colony-forming assay identifies samples with the greatest potential to propagate and differentiate. Br. J. Haematol. 1999, 107, 275-281. [CrossRef]

17. Zuk, P.A.; Zhu, M.; Ashjian, P.; De Ugarte, D.A.; Huang, J.I.; Mizuno, H.; Alfonso, Z.C.; Fraser, J.K.; Benhaim, P.; Hedrick, M.H. Human adipose tissue is a source of multipotent stem cells. Mol. Biol. Cell 2002, 13, 4279-4295. [CrossRef]

18. Kim, D.-W.; Staples, M.; Shinozuka, K.; Pantcheva, P.; Kang, S.-D.; Borlongan, C.V. Wharton's Jelly-Derived Mesenchymal Stem Cells: Phenotypic Characterization and Optimizing Their Therapeutic Potential for Clinical Applications. Int. J. Mol. Sci. 2013, 14, 11692-11712. [CrossRef]

19. Rocca, G.L. Editorial-Connecting the Dots: The Promises of Wharton's Jelly Mesenchymal Stem Cells forTissue Repair and Regen-eration. Open Tissue Eng. Regen. Med. J. 2011, 4, 3-5. [CrossRef]

20. Pelekanos, R.A.; Sardesai, V.S.; Futrega, K.; Lott, W.B.; Kuhn, M.; Doran, M.R. Isolation and Expansion of Mesenchymal Stem/Stromal Cells Derived from Human Placenta Tissue. J. Vis. Exp. 2016, 10, e54204. [CrossRef]

21. Araújo, A.B.; Furlan, J.M.; Salton, G.D.; Schmalfuss, T.; Röhsig, L.M.; Silla, L.M.R.; Passos, E.P.; Paz, A.H. Isolation of human mesenchymal stem cells from amnion, chorion, placental decidua and umbilical cord: Comparison of four enzymatic protocols. Biotechnol. Lett. 2018, 40, 989-998. [CrossRef] [PubMed]

22. Secunda, R.; Vennila, R.; Mohanashankar, A.M.; Rajasundari, M.; Jeswanth, S.; Surendran, R. Isolation, expansion and characterisation of mesenchymal stem cells from human bone marrow, adipose tissue, umbilical cord blood and matrix: A comparative study. Cytotechnology 2015, 67, 793-807. [CrossRef] [PubMed]

23. Abrams, M.B.; Dominguez, C.; Pernold, K.; Reger, R.; Wiesenfeld-Hallin, Z.; Olson, L.; Prockop, D. Multipotent mesenchymal stromal cells attenuate chronic inflammation and injury-induced sensitivity to me-chanical stimuli in experimental spinal cord injury. Restor. Neurol. Neurosci. 2009, 27, 307-321. [PubMed]

24. Jiang, W.; Xu, J. Immune modulation by mesenchymal stem cells. Cell Prolif. 2019, 53, e12712. [CrossRef] [PubMed]

25. Yan, K.; Zhang, R.; Sun, C.; Chen, L.; Li, P.; Liu, Y.; Peng, L.; Sun, H.; Qin, K.; Chen, F.; et al. Bone marrow-derived mesenchymal stem cells maintain the resting phenotype of microglia and inhibit microglial acti-vation. PLoS ONE 2013, 8, e84116. [CrossRef] [PubMed]

26. Kruminis-Kaszkiel, E.; Osowski, A.; Bejer-Oleńska, E.; Dziekoński, M.; Wojtkiewicz, J. Differentiation of Human Mesenchymal Stem Cells from Wharton's Jelly Towards Neural Stem Cells Using a Feasible and Repeatable Protocol. Cells 2020, 9, 739. [CrossRef] [PubMed]

27. Liau, L.L.; Looi, Q.H.; Chia, W.C.; Subramaniam, T.; Ng, M.H.; Law, J.X. Treatment of spinal cord injury with mesenchymal stem cells. Cell Biosci. 2020, 10, 1-17. [CrossRef]

28. Voulgari-Kokota, A.; Fairless, R.; Karamita, M.; Kyrargyri, V.; Tseveleki, V.; Evangelidou, M.; Delorme, B.; Charbord, P.; Diem, R.; Probert, L. Mesenchymal stem cells protect CNS neurons against glutamate excitotoxicity by inhibiting glutamate receptor expression and function. Exp. Neurol. 2012, 236, 161-170. [CrossRef]

29. Cantinieaux, D.; Quertainmont, R.; Blacher, S.; Rossi, L.; Wanet, T.; Noel, A.; Brook, G.; Schoenen, J.; Franzen, R. Conditioned Medium from Bone Marrow-Derived Mesenchymal Stem Cells Improves Recovery after Spinal Cord Injury in Rats: An Original Strategy to Avoid Cell Transplantation. PLoS ONE 2013, 8, e69515. [CrossRef]

30. Crigler, L.; Robey, R.C.; Asawachaicharn, A.; Gaupp, D.; Phinney, D. Human mesenchymal stem cell subpopulations express a variety of neuro-regulatory molecules and promote neuronal cell survival and neuritogenesis. Exp. Neurol. 2006, 198, 54-64. [CrossRef]

31. Aggarwal, S.; Pittenger, M.F. Human mesenchymal stem cells modulate allogeneic immune cell responses. Blood 2005, 105, 1815-1822. [CrossRef] [PubMed]

32. Chopp, M.; Li, Y. Treatment of neural injury with marrow stromal cells. Lancet Neurol. 2002, 1, 92-100. [CrossRef]

33. Jakob, F.; Limbert, C.; Schilling, T.; Benisch, P.; Seefried, L.; Ebert, R. Biology of Mesenchymal Stem Cells. Curr. Rheumatol. Rev. 2008, 4, 148-154. [CrossRef]

34. Hamano, K.; Li, T.-S.; Kobayashi, T.; Kobayashi, S.; Matsuzaki, M.; Esato, K. Angiogenesis Induced by the Implantation of Self-Bone Marrow Cells: A New Material for Therapeutic Angiogenesis. Cell Transplant. 2000, 9, 439-443. [CrossRef]

35. Park, C.W.; Kim, K.-S.; Bae, S.; Son, H.K.; Myung, P.-K.; Hong, H.J.; Kim, H. Cytokine Secretion Profiling of Human Mesenchymal Stem Cells by Antibody Array. Int. J. Stem Cells 2009, 2, 59-68. [CrossRef]

36. Schiff, L.; Hadker, N.; Weiser, S.; Rausch, C. A literature review of the feasibility of glial fibrillary acidic protein as a biomarker for stroke and traumatic brain injury. Mol. Diagn. Ther. 2012, 16, 79-92. [CrossRef]

37. Mayer, C.A.; Brunkhorst, R.; Niessner, M.; Pfeilschifter, W.; Steinmetz, H.; Foerch, C. Blood Levels of Glial Fibrillary Acidic Protein (GFAP) in Patients with Neurological Diseases. PLoS ONE 2013, 8, e62101. [CrossRef]

38. Sedaghat, F.; Notopoulos, A. S100 protein family and its application in clinical practice. Hippokratia 2008, 12, 198-204. 
39. Cao, F.; Yang, X.F.; Liu, W.G.; Hu, W.W.; Li, G.; Zheng, X.J.; Shen, F.; Zhao, X.Q.; Lv, S.T. Elevation of neuron-specific enolase and S-100beta protein level in experimental acute spinal cord injury. J. Clin. Neurosci. 2008, 15, 541-544. [CrossRef]

40. Faridaalee, G.; Khajeh, F.K. Serum and Cerebrospinal Fluid Levels of S-100ß Is A Biomarker for Spinal Cord Injury; a Systematic Review and Meta-Analysis. Arch. Acad. Emerg. Med. 2019, 7, e19.

41. Shaw, G.; Yang, C.; Ellis, R.; Anderson, K.; Mickle, J.P.; Scheff, S.; Pike, B.; Anderson, D.K.; Howland, D.R. Hyperphosphorylated neurofilament NF-H is a serum biomarker of axonal injury. Biochem. Biophys. Res. Commun. 2005, 336, 1268-1277. [CrossRef] [PubMed]

42. Boylan, K.B.; Glass, J.D.; Crook, J.E.; Yang, C.; Thomas, C.S.; Desaro, P.; Johnston, A.; Overstreet, K.; Kelly, C.; Polak, M.; et al Phosphorylated neurofilament heavy subunit (pNF-H) in peripheral blood and CSF as a potential prognostic bi-omarker in amyotrophic lateral sclerosis. J. Neurol. Neurosurg. Psychiatry 2013, 84, 467-472. [CrossRef] [PubMed]

43. Lewis, S.B.; Wolper, R.A.; Miralia, L.; Yang, C.; Shaw, G. Detection of phosphorylated NF-H in the cerebrospinal fluid and blood of aneurysmal subarachnoid hemorrhage patients. J. Cereb. Blood Flow Metab. 2008, 28, 1261-1271. [CrossRef] [PubMed]

44. St, M.I.; Ungureanu, D.; Tascu, A.; Costachescu, B.; Iencean, A.S.; Poeata, I. CSF phosphorylated neurofilament subunit NF-H (pNF-H) levels are biomarkers of Spinal Cord Injury. Rom. Neurosurg. 2013, 148-450.

45. Bartlett, R.D.; Burley, S.; Ip, M.; Phillips, J.B.; Choi, D. Cell Therapies for Spinal Cord Injury: Trends and Challenges of Current Clinical Trials. Neurosurgery 2020, 87, E456-E472. [CrossRef] [PubMed]

46. Karamouzian, S.; Nematollahi-Mahani, S.N.; Nakhaee, N.; Eskandary, H. Clinical safety and primary efficacy of bone marrow mesenchymal cell transplantation in subacute spinal cord injured patients. Clin. Neurol. Neurosurg. 2012, 114, 935-939. [CrossRef]

47. Upadhyayula, P.S.; Martin, J.R.; Rennert, R.C.; Ciacci, J.D. Review of operative considerations in spinal cord stem cell therapy. World J. Stem Cells 2021, 13, 168-176. [CrossRef]

48. Yamaguchi, S.; Horie, N.; Satoh, K.; Ishikawa, T.; Mori, T.; Maeda, H.; Fukuda, Y.; Hiu, T.; Morofuji, Y.; Izumo, T. Age of donor of human mesenchymal stem cells affects structural and functional recovery after cell therapy following ischaemic stroke. Br. J. Pharmacol. 2017, 38, 1199-1212. [CrossRef]

49. Rezniczek, G.A.; Kumbruch, S.; Scheich, J.; Jensen, A.; Tempfer, C.B. Factors influencing yield and neuronal differentiation of mesenchymal stem cells from umbilical cord blood and matrix. Regen. Med. 2016, 11, 465-474. [CrossRef]

50. Takahashi, H.; Aoki, Y.; Nakajima, A.; Sonobe, M.; Terajima, F.; Saito, M.; Taniguchi, S.; Yamada, M.; Watanabe, F.; Furuya, T.; et al. Phosphorylated neurofilament subunit NF-H becomes elevated in the cerebrospinal fluid of patients with acutely worsening symptoms of compression myelopathy. J. Clin. Neurosci. 2014, 21, 2175-2178. [CrossRef]

51. Ahadi, R.; Khodagholi, F.; Daneshi, A.; Vafaei, A.; Mafi, A.A.; Jorjani, M. Diagnostic Value of Serum Levels of GFAP, pNF-H, and NSE Compared with Clinical Findings in Severity Assessment of Human Traumatic Spinal Cord Injury. Spine 2015, 40, E823-E830. [CrossRef]

52. Hayakawa, K.; Okazaki, R.; Ishii, K.; Ueno, T.; Izawa, N.; Tanaka, Y.; Toyooka, S.; Matsuoka, N.; Morioka, K.; Ohori, Y.; et al. Phosphorylated neurofilament subunit NF-H as a biomarker for evaluating the severity of spinal cord injury patients, a pilot study. Spinal Cord 2012, 50, 493-496. [CrossRef]

53. Singh, A.; Kumar, V.; Ali, S.; Mahdi, A.A.; Srivastava, R.N. Phosphorylated neurofilament heavy: A potential blood biomarker to evaluate the severity of acute spinal cord injuries in adults. Int. J. Crit. Illn. Inj. Sci. 2017, 7, 212-217. [CrossRef]

54. Abdelhak, A.; Huss, A.; Kassubek, J.; Tumani, H.; Otto, M. Serum GFAP as a biomarker for disease severity in multiple sclerosis. Sci. Rep. 2018, 8, 1-7. [CrossRef]

55. Matute-Blanch, C.; Montalban, X.; Comabella, M. Multiple sclerosis, and other demyelinating and autoimmune inflammatory diseases of the central nervous system. Cerebellum Embryol. Diagn. Investig. 2018, 146, 67-84. [CrossRef]

56. Holmström, U.; Tsitsopoulos, P.P.; Holtz, A.; Salci, K.; Shaw, G.; Mondello, S.; Marklund, N. Cerebrospinal fluid levels of GFAP and pNF-H are elevated in patients with chronic spinal cord injury and neurological deterioration. Acta Neurochir. 2020, 162, 2075-2086. [CrossRef]

57. Petzold, A.; Shaw, G. Comparison of two ELISA methods for measuring levels of the phosphorylated neurofilament heavy chain. J. Immunol. Methods 2007, 319, 34-40. [CrossRef]

58. Harrop, J.S.; Hashimoto, R.; Norvell, D.; Raich, A.; Aarabi, B.; Grossman, R.G.; Guest, J.D.; Tator, C.H.; Chapman, J.; Fehlings, M. Evaluation of clinical experience using cell-based therapies in patients with spinal cord injury: A systematic review. J. Neurosurg. Spine 2012, 17, 230-246. [CrossRef]

59. Sofroniew, M.V. Molecular dissection of reactive astrogliosis and glial scar formation. Trends Neurosci. 2009, 32, 638-647. [CrossRef]

60. Borlongan, C.V.; Zhang, Y.; Yu, S.; Tuazon, J.P.; Lee, J.-Y.; Corey, S.; Kvederis, L.; Kingsbury, C.; Kaneko, Y. Neuroprotective effects of human bone marrow mesenchymal stem cells against cerebral ischemia are mediated in part by an anti-apoptotic mechanism. Neural Regen. Res. 2019, 14, 597-604. [CrossRef]

61. Huang, W.; Lv, B.; Zeng, H.; Shi, D.; Liu, Y.; Chen, F.; Li, F.; Liu, X.; Zhu, R.; Yu, L.; et al. Paracrine Factors Secreted by MSCs Promote Astrocyte Survival Associated with GFAP Downregulation After Ischemic Stroke via p38 MAPK and JNK. J. Cell. Physiol. 2015, 230, 2461-2475. [CrossRef]

62. Moore, K.W.; de Waal Malefyt, R.; Coffman, R.L.; O'Garra, A. Interleukin-10 and the interleukin-10 receptor. Annu. Rev. Immunol. 2001, 19, 683-765. [CrossRef]

63. Zhou, Z.; Peng, X.; Insolera, R.; Fink, D.J.; Mata, M. Interleukin-10 provides direct trophic support to neurons. J. Neurochem. 2009, 110, 1617-1627. [CrossRef] 
64. Zhou, Z.; Peng, X.; Insolera, R.; Fink, D.J.; Mata, M. IL-10 promotes neuronal survival following spinal cord injury. Exp. Neurol. 2009, 220, 183-190. [CrossRef]

65. Plunkett, J.A.; Yu, C.-G.; Easton, J.M.; Bethea, J.R.; Yezierski, R.P. Effects of Interleukin-10 (IL-10) on Pain Behavior and Gene Expression Following Excitotoxic Spinal Cord Injury in the Rat. Exp. Neurol. 2001, 168, 144-154. [CrossRef]

66. Yu, Z.; Sun, X.; Xia, R.; Chen, Q.; Wu, Q.; Zheng, W. Modulation of inflammatory factors predicts the outcome following spinal cord injury. J. Orthop. Surg. Res. 2020, 15, 199. [CrossRef]

67. Palmer, G.; Guerne, P.A.; Mezin, F.; Maret, M.; Guicheux, J.; Goldring, M.B.; Gabay, C. Production of interleukin-1 receptor antagonist by human articular chondrocytes. Arthritis Res. 2002, 4, 226-231. [CrossRef]

68. Bickel, M. The role of interleukin-8 in inflammation and mechanisms of regulation. J. Periodontol. 1993, 64, 456-460.

69. Wang, L.; Li, Y.; Zhang, X.; Liu, N.; Shen, S.; Sun, S.; Jiang, Y.; Li, P.; Jin, H.; Shen, L. Paracrine interleukin-8 affects mesenchymal stem cells through the Akt pathway and enhances human umbilical vein endothelial cell proliferation and migration. Biosci. Rep. 2021, 41. [CrossRef]

70. Liu, M.; Guo, S.; Hibbert, J.M.; Jain, V.; Singh, N.; Wilson, N.O.; Stiles, J.K. CXCL10/IP-10 in infectious diseases pathogenesis and potential therapeutic implications. Cytokine Growth Factor Rev. 2011, 22, 121-130. [CrossRef]

71. Yu, Q.; Tian, D.L.; Tian, Y.; Zhao, X.T.; Yang, X.Y. Elevation of the Chemokine Pair CXCL10/CXCR3 Initiates Sequential Glial Activation and Crosstalk During the De-velopment of Bimodal Inflammatory Pain after Spinal Cord Ischemia Reperfusion. Cell. Physiol. Biochem. 2018, 9, 2214-2228. [CrossRef] [PubMed]

72. Babcock, A.A.; Kuziel, W.A.; Rivest, S.; Owens, T. Chemokine Expression by Glial Cells Directs Leukocytes to Sites of Axonal Injury in the CNS. J. Neurosci. 2003, 23, 7922-7930. [CrossRef] [PubMed]

73. Zaaqoq, A.M.; Namas, R.; Almahmoud, K.; Azhar, N.; Mi, Q.; Zamora, R.; Brienza, D.M.; Billiar, T.R.; Vodovotz, Y. Inducible Protein-10, a Potential Driver of Neurally Controlled Interleukin-10 and Morbidity in Human Blunt Trauma*. Crit. Care Med. 2014, 42, 1487-1497. [CrossRef] [PubMed]

74. Yagura, K.; Ohtaki, H.; Tsumuraya, T.; Sato, A.; Miyamoto, K.; Kawada, N.; Suzuki, K.; Nakamura, M.; Kanzaki, K.; Dohi, K.; et al. The enhancement of CCL2 and CCL5 by human bone marrow-derived mesenchymal stem/stromal cells might contribute to inflammatory suppression and axonal extension after spinal cord injury. PLoS ONE 2020, 15, e0230080. [CrossRef] [PubMed]

75. Matthews, A.N.; Friend, D.S.; Zimmermann, N.; Wert, S.E.; Rothenberg, M.E. Eotaxin is required for the baseline level of tissue eosinophils. Proc. Natl. Acad. Sci. USA 1998, 95, 6273-6278. [CrossRef] [PubMed]

76. Niemi, J.; DeFrancesco-Lisowitz, A.; Cregg, J.; Howarth, M.; Zigmond, R.E. Overexpression of the monocyte chemokine CCL2 in dorsal root ganglion neurons causes a conditioning-like increase in neurite outgrowth and does so via a STAT3 dependent mechanism. Exp. Neurol. 2016, 275, 25-37. [CrossRef] [PubMed]

77. De Santana Nunes, A.K.; Rapôso, C.; de Oliveira, W.H.; Thomé, R.; Verinaud, L.; Tovar-Moll, F.; Peixoto, C.A. Phosphodiesterase-5 inhibition promotes remyelination by MCP-1/CCR-2 and MMP-9 regulation in a cu-prizone-induced demyelination model. Exp. Neurol. 2016, 275, 143-153. [CrossRef]

78. Tokami, H.; Ago, T.; Sugimori, H.; Kuroda, J.; Awano, H.; Suzuki, K.; Kiyohara, Y.; Kamouchi, M.; Kitazono, T. RANTES has a potential to play a neuroprotective role in an autocrine/paracrine manner after ischemic stroke. Brain Res. 2013, 1517, 122-132. [CrossRef]

79. Olbrich, L.; Foehring, D.; Happel, P.; Brand-Saberi, B.; Theiss, C. Fast rearrangement of the neuronal growth cone's actin cytoskeleton following VEGF stimulation. Histochem. Cell Biol. 2013, 139, 431-445. [CrossRef]

80. Schlau, M.; Terheyden-Keighley, D.; Theis, V.; Mannherz, H.G.; Theiss, C. VEGF Triggers the Activation of Cofilin and the Arp2/3 Complex within the Growth Cone. Int. J. Mol. Sci. 2018, 19, 384. [CrossRef]

81. Silva-Hucha, S.; Pastor, A.; Morcuende, S. Neuroprotective Effect of Vascular Endothelial Growth Factor on Motoneurons of the Oculomotor System. Int. J. Mol. Sci. 2021, 22, 814. [CrossRef] [PubMed]

82. Figley, S.A.; Liu, Y.; Karadimas, S.K.; Satkunendrarajah, K.; Fettes, P.; Spratt, S.K.; Lee, G.; Ando, D.; Surosky, R.; Giedlin, M.; et al. Delayed administration of a bio-engineered zinc-finger VEGF-A gene therapy is neuroprotective and attenuates allodynia following traumatic spinal cord injury. PLoS ONE 2014, 9, e96137. [CrossRef] [PubMed]

83. Idrisova, K.F.; Rizvanov, A.A.; Zeinalova, A.K.; Masgutova, G.A.; Bogov, A.A.; Allegrucci, C.; Syromiatnikova, V.Y.; SalafutdinovI, I.; Garanina, E.E.; Andreeva, D.I.; et al. Application of neurotrophic and proangiogenic factors as therapy after peripheral nervous system injury. Neural Regen. Res. 2022, 17, 1240. [CrossRef] [PubMed]

84. Liu, B.; Neufeld, A.H. Activation of epidermal growth factor receptor causes astrocytes to form cribriform structures. Glia 2004, 46, 153-168. [CrossRef]

85. Li, Z.W.; Li, J.J.; Wang, L.; Zhang, J.P.; Wu, J.J.; Mao, X.Q.; Shi, G.F.; Wang, Q.; Wang, F.; Zou, J. Epidermal growth factor receptor inhibitor ameliorates excessive astrogliosis and improves the regeneration microen-vironment and functional recovery in adult rats following spinal cord injury. J. Neuroinflamm. 2014, 11, 71. [CrossRef] 